\title{
Manuskrip al-Qur'an di Alam Melayu: Kajian Terhadap Manuskrip al-Qur'an Terengganu
}

\author{
Riswadi Azmi \\ Universiti Malaya,riswadi@umt.edu.my \\ Mustaffa Abdullah \\ Universiti Malaya,mustaffa@um.edu.my
}

\begin{abstract}
Abstrak
Fokus utama artikel ini adalah untuk menghuraikan sejarah manuskrip alQur'an yang berada di Alam Melayu seterusnya memperjelaskan secara terperinci berkenaan sejarah manuskrip al-Qur'an Terengganu. Selain itu artikel ini juga memberi tumpuan terhadap ciri-ciri yang terdapat pada manuskrip al-Qur'an Terengganu dan taburannya yang berlokasi di dalam dan luar negara. Manuskrip al-Qur'an Terengganu ini dikatakan antara yang terbaik yang pernah dihasilkan di Alam Melayu sekitar abad ke 18-19 M. Lawatan kajian ke beberapa tempat telah diadakan bagi mengenalpasti, mendokumentasi dan menjalankan kerja-kerja pendigitalan terhadap semua manuskrip al-Qur'an Terengganu. Perbandingan antara lain-lain manuskrip al-Qur'an Alam Melayu juga dilakukan untuk melihat beberapa aspek penting seperti iluminasi, kaligrafi dan metodologi penulisan manuskrip al-Qur'an. Melalui metode historis, kajian terhadap aspek sejarah dan latar belakang manuskrip dapat dikenalpasti dan dijelaskan. Dapatan kajian mendapati sembilan manuskrip al-Qur'an Terengganu telah dijumpai dan berada yang di beberapa tempat dalam dan luar negara. Kesemua manuskrip al-Qur'an ini mempunyai ciri-ciri yang sama terutama pada aspek iluminasi. Ciri hiasan yang mewah yang terdapat pada manuskrip-manuskrip al-Qur'an ini menggambarkan bahawa ianya dihasilkan oleh institusi diraja Terengganu dan ianya juga lengkap serta kemas pada aspek kaligrafinya membuktikan kearifan lokal yang berada di Alam Melayu ketika itu. Diharap artikel ini memperjelaskan kepada masyarakat akan keunggulan manuskrip al-Qur'an Terengganu dan juga memberi kepada masyarakat supaya mengiktiraf manuskrip al-Qur'an ini sebagai warisan agung yang perlu dipelihara agar generasi mengagumi kesarjanaan dan kepakaran sarjana lokal.
\end{abstract}

Kata kunci: manuskrip al-Qur'an, Alam Melayu, sejarah penulisan, Terengganu 


\title{
Manuscript of al-Qur'an in the Malay World: Study on the Terengganu al-Qur'an Manuscript
}

\begin{abstract}
The main focus of this article is to elucidate the history of the Qur'an manuscripts in the Malay World and further clarify in detail the history of the Terengganu al-Quran manuscripts. In addition, this article also focuses on the features found in the Terengganu al-Quran manuscripts and their distribution locally and abroad. This Terengganu al-Quran manuscript is said to be among the best ever made in the Malay world around the 18th century 19th century. A study visit to several places was held to identify, document and conduct digitization works on all the Terengganu al-Quran manuscripts. Comparisons between other Malay World Qur'an manuscripts are also performed to see some important aspects such as illumination, calligraphy and methodology of the writing of the Qur'an manuscript. Through historical methods, studies on the historical and theoretical aspects of the manuscript can be identified and explained. The findings show that nine manuscripts of the Terengganu alphabet have been found and located in various places within and outside the country. All of these manuscripts of the Qur'an have the same characteristics especially in the aspects of illumination. The luxurious decoration features found in the manuscripts of the Qur'an illustrates that it was produced by Terengganu royal institutions and it is also complete and neat on the aspect of its calligraphy proving the local wisdom in the Malay world at that time. It is hoped that this article will explain to the public the excellence of the Terengganu al-Quran manuscripts and also give the people the recognition of this al-Qur'an manuscript as a great legacy that needs to be maintained so that generations will admire scholarship and local scholarship expertise.
\end{abstract}

Keywords: al-Qur'an manuscript, the Malay World, writing history, Terengganu

\section{Pendahuluan}

Sejarah penulisan al-Qur'an telah bermula semasa zaman penurunan wahyu kepada nabi Muhammad SAW. Selama 23 tahun proses penurunan wahyu ini berlaku, mushaf al-Qur'an tidak dikumpulkan dan ianya berada pada setiap sahabat yang menulis atau menyalin untuk simpanan peribadi. Sehinggalah Sayidina Abu Bakar bertindak untuk mengumpulkannya. Seterusnya usaha yang lebih tersusun dan komprehensif terhadap pengumpulan dan penulisan semula al-Qur'an diteruskan oleh Sayidina Uthman. 
Hasil usaha yang besar ini, al-Qur'an Mushaf Uthmani ${ }^{1}$ dijadikan dasar acuan bagi proses penyalinan al-Qur'an diseluruh dunia Islam $^{2}$. Perkembangan penulisan Mushaf Uthmani ini juga telah menjadi acuan dan dasar penyalinan al-Qur'an di Alam Melayu .

Penulisan atau penyalinan al-Qur'an di Alam Melayu dijangkakan telah bermula sekurang-kurangnya sekitar akhir abad ke-13 M. Ia berlaku ketika Pasai iaitu suatu negeri yang terletak di hujung kepulauan Sumatera menjadi kerajaan pertama di Alam Melayu yang memeluk Islam setelah pengislaman Sultan atau Raja mereka. Walau bagaimanapun penulisan manuskrip ilmu-ilmu Islam yang menggunakan kertas di Asia Tenggara hanya bermula daripada abad ke-16 M dan kebanyakannya bermula di awal abad ke-19 M. Manakala manuskrip al-Qur'an yang sempurna pada aspek hiasan iluminasinya yang dijumpai setakat ini dipercayai dihasilkan pada abad ke-17 $\mathrm{M}^{3}$.

Bagi mengetahui apakah manuskrip al-Qur'an yang paling tua di Alam Melayu, Annabel Teh Gallop ${ }^{4}$ telah membuat kajian terhadap beberapa tempat di Britain terutamanya manuskrip yang menjadi koleksi William Marsden ${ }^{5}$, beliau telah melihat sebuah manuskrip al-Qur'an bernombor MS12716 yang mempunyai kolofon berbahasa Arab, bertarikh Jamadil Awal 993 bersamaan 1585 M. Berdasarkan kepada kertas, kaedah penjilidan, fizikal

1 Mushaf ini dikenali dengan nama Mushaf Uthmani. Menurut pandangan sejarawan Islam diantaranya Ibnu Kathir, Uthman r.a. berjaya menghasilkan 7 buah salinan mushaf al-Qur'an. Satu salinan telah disimpan di Madinah dan dikenali dengan mana Mushaf al-Imam. Dan enam salinan yang lainnya telah dihantar ke Mekah, Kufah, Basrah, Syam, Yaman dan Bahrain. Ismā'īl bin Kathīr, Tafsīr al-Qur'ān al-'Ażìm (Beirut: Dār al-Kutub al-'Ilmiyyah, t.t.), $4: 15$.

${ }^{2}$. Ibu Kathir, Tafsīr al-Qur'ān al- 'Ažìm, 18.

3 Annabel Teh Gallop, "The Art of the Qur'an in Southeast Asia," dalam Word of God, Art of Man, The Qur'an and its Creative Expressions, ed. Fahmida Suleman (Oxford: The Institute of Ismaili Studies London, 2010), 192.

4 Annabel Teh Gallop, "The Art of the Qur'an in Southeast Asia," dalam Word of God, Art of Man, The Qur'an and its Creative Expressions, 193.

${ }^{5}$ William Marsden merupakan seorang pengumpul manuskrip Alam Melayu yang pernah berkerja di Bengkulu, Indonesia pada akhir abad ke-18. Semasa selesai bertugas di Indonesia, beliau telah membawa pulang sebahagian besar manuskrip ke Britain. Dan sekarang koleksi beliau telah disimpan di Perpustakaan School of Oriental and African Studies, University of London. Fadhal AR Bafadal dan Rosehan Anwar ed. , Mushaf-Mushaf Kuno Indonesia, vii. 
manuskrip dan kaligrafinya, beliau membuat kesimpulan bahawa manuskrip ini merupakan manuskrip al-Qur'an yang paling lama yang pernah dihasilkan di Alam Melayu .

Manuskrip al-Qur'an yang kedua tertua adalah yang bertarikh 7 Dhu al-Qa'īdah $1005 \mathrm{H}$ bersamaan $1597 \mathrm{M}$. Walaupun ianya manuskrip al-Qur'an yang kedua tertua, namun manuskrip ini mempunyai kelebihannya yang tersendiri apabila ianya mempunyai kolofon yang tertulis nama penulisnya iaitu Afif alDīn 'Abd al-Bāqī bin 'Abd Allāh al-Adnī. Selain itu manuskrip ini memaparkan tempat ianya dihasilkan iaitu Ternate, Maluku Utara, Indonesia ${ }^{6}$.

Penulisan manuskrip al-Qur'an di Alam Melayu bergerak lebih pantas ekoran kesedaran masyarakat ketika itu untuk menguasai al-Qur'an. Lebih banyak manuskrip al-Qur'an mula dihasilkan pada abad ke-19 M atau awal abad ke $20 \mathrm{M}$ dipelbagai tempat dan kawasan. Antara kawasan yang agak signifikan dalam penghasilan manuskrip al-Qur'an ini ialah Acheh, Banten, Sumatera, Sulawesi Selatan, Terengganu, Patani, Kedah, Yogjakarta, Cirebon, Mindanao dan lain-lain tempat di Asia Tenggara ${ }^{7}$.

\section{Sejarah Perkembangan al-Qur'an Terengganu Sehingga Abad ke-19 M}

Kedatangan Islam di Terengganu dikira permulaannya apabila Batu Bersurat Terengganu telah mencatatkan pelaksanaan undangundang Islam di Negeri ini pada tahun 1303 M lagi. Walaupun ianya telah bermula awal, namun tiada bukti sejarah setakat ini yang membuktikan penulisan al-Qur'an telah bermula pada waktu seawal itu. Namun begitu, tidak boleh dinafikan bahawa tiada alQur'an yang berada pada waktu itu kerana kedatangan dan perkembangan Islam tidak dapat tidak mesti berselari dengan alQur'an sebagai kitab suci agama Islam.

Bagi meneliti sejarah penulisan al-Qur'an di Terengganu, pengkaji membahagikan sejarah penulisan al-Qur'an di Terengganu ini kepada dua fasa sebagaimana berikut.

6 Fadhal AR Bafadal dan Rosehan Anwar ed., Mushaf-Mushaf Kuno Indonesia, viii.

7 Fadhal AR Bafadal dan Rosehan Anwar ed., Mushaf-Mushaf Kuno Indonesia, viii. 


\section{Sejarah Penulisan Al-Qur'an}

Perkembangan sejarah penulisan (menggunakan kertas) di Terengganu pada umumnya bermula pada zaman Sultan Zainal Abidin Shah I, iaitu pengasas kesultanan Terengganu, baginda merupakan putera Tun Habib Abdul Majid, iaitu bendahara Johor yang ke-18. Pada zaman pemerintahan Baginda (1708-1733), ramai ulama' Terengganu yang telah menulis kitab, antaranya Sheikh Abdul Malik bin Abdullah (Tok Pulau Manis) yang bukan sahaja berperanan sebagai penasihat pribadi Baginda, bahkan juga telah memberi sumbangan dalam penulisan antaranya terjemahan kitab Hikam Ibni Ata'illah dan menyusun beberapa buah kitab seperti Kitab Kifayah dan Risalah Nuqil ${ }^{8}$.

Penulisan al-Qur'an menggunakan kertas sudah pasti telah bermula seiring dengan penulisan kitab-kitab agama oleh ulama'ulama' pada zaman itu atau mungkin sebelumnya. Namun masih belum ditemukan al-Qur'an berkolofon yang paling awal di Terengganu semasa abad ke-17 atau $18 \mathrm{M}$. Walaupun begitu, manuskrip al-Qur'an yang menjadi koleksi di Muzium Kesenian Islam Malaysia mungkin boleh dijadikan fakta setakat ini bahawa ianya merupakan al-Qur'an berkolofon yang terawal di Terengganu dan pemulaan kepada penulisan al-Qur'an beriluminasi indah. Manuskrip al-Qur'an IAMM 1998. 1. 3427 ini pada asalnya menjadi koleksi di Pusat Islam Malaysia (Bahagian Hal Ehwal Islam, Jabatan Perdana Menteri, namunnya ianya telah diserahkan kepada Muzium Kesenian Islam pada tahun 1997. Manuskrip ini berukuran folio $43 \mathrm{~cm}$ panjang dan $28 \mathrm{~cm}$ lebar ini merupakan saiz yang agak besar berbanding dengan manuskrip alQur'an Terengganu yang lain. Pada halaman akhir manuskrip ini, mempunyai jadual rumuz tanda wakaf dan tercatat tarikh sempurna penulisan pada tahun 1288 hijrah bersamaan $1872 \mathrm{M}^{9}$. Tarikh kolofonnya agak baru berbanding lain-lain manuskrip yang terdapat di Alam Melayu yang seperti manuskrip al-Qur'an Kedah $1753 \mathrm{M}^{10}$ dan manuskrip al-Qur'an dari kesultanan Ternate,

${ }^{8}$ Mohamed Anuar Omar Din dan Nik Anuar Mahmud, Sejarah Kesultanan Terengganu 1708-2008 (Kuala Terengganu: Yayasan DiRaja Sultan Mizan, 2011), 220.

9 Al-Qur'an, no. IAMM 1998. 1. 3427 (folio 611), Kuala Lumpur: Muzium Kesenian Islam Malaysia.

${ }^{10}$ Riswadi Azmi, "Manuskrip al-Qur'an di Masjid Raya Sultan Riau; Kajian Diskriptif dan Analisis Teks Qira'at'. Makalah, The International Symposium 
Maluku Utara, Indonesia yang dihasilkan pada tahun 1597 M. Walaupun tarikhnya agak baru, namun hiasan iluminasinya adalah yang terbaik di Alam Melayu dan penggunaan emas pada hiasannya agak mewah dan terserlah ${ }^{11}$.

Gambar 1.1. Catatan tarikh pada manuskrip al-Qur'an Terengganu IAMM 1998.1. 3427

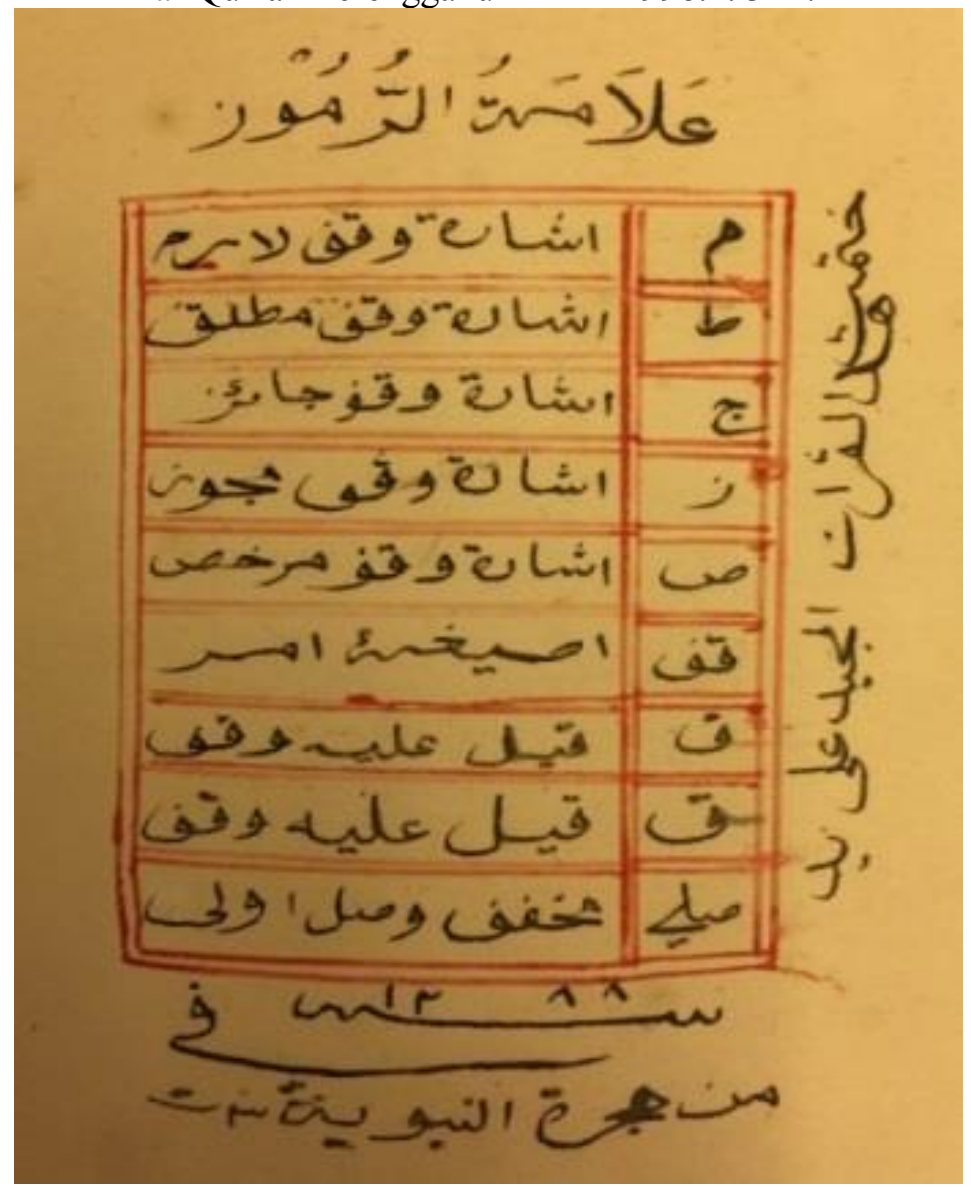

on Manuscript of Qur'an Science and Interpretations: The indexing, Definition, Description and Study, Center Of Quranic Research, Universiti Malaya, 29-30 Ogos 2012.

${ }^{11}$ Annabel Teh Gallop, "The spirit of Langkasuka? Illuminated manuscripts from the East Coast of the Malay Peninsula," dalam Indonesia and the Malay World (London: Routledge, 2005), 84. 
Berdasarkan kepada tarikh sempurna manuskrip ini secara jelasnya ianya dihasilkan ketika zaman pemerintahan Baginda Sultan Omar iaitu tahun 1831 (pemerintahan pertama) dan 18391876 (pemerintahan kedua). Seterusnya penulisan al-Qur'an Terengganu berkembang sehingga merentasi sempadan negara, sehingga ada manuskrip al-Qur'an Terengganu berpindah ke kesultanan Bima ${ }^{12}$ dan sekarang menjadi koleksi di Bayt al-Qur'an dan Muzium Istiqlal, Jakarta. Perkembangan penulisan ini dilihat lebih rancak ketika zaman pemerintahan Sultan Zainal Abdin III atau dikenali sebagai Marhum Haji (1881-1918). Baginda dicatat sebagai Sultan yang menguasai pelbagai disiplin ilmu terutama 'ilmu agama dan ketika zaman pemerintahannya Baginda telah mengembangkan ramai intelektual Melayu sehingga lahirnya ulama'-ulama' yang banyak mengarang kitab-kitab pada zamannya $^{13}$. Terdapat beberapa buah manuskrip al-Qur'an telah dihasilkan ketika zamannya, antaranya manuskrip al-Qur'an IAMM 1998.1.3436 yang mempunyai kolofon yang agak lengkap berbanding IAMM 1998.1.3427. Kolofonnya tercatat tarikh 13 Sya'aban 1275 hijrah bersamaan 18 Mac 1859 M. Selain tarikh ianya dihasilkan, manuskrip ini juga mengandungi nama penulis iaitu Haji Ahmad dan nama tempat iaitu Kampung Menjelagi. Kampung ini terletak di daerah Besut, Terengganu.

\section{Sejarah Percetakan Al-Qur'an}

Dalam sejarah dunia percetakan al-Qur'an, negara Mesir telah memulakan langkah yang proaktif menjadi antara negara awal yang mempelopori teknologi percetakan al-Qur'an iaitu sekitar tahun 1798, hal ini berlaku setelah melihat keperluan ummat Islam untuk memiliki al-Qur'an. Pada waktu itu al-Qur'an dicetak per

\footnotetext{
${ }^{12}$ Bima merupakan nama tempat yang terletak di bahagian barat Nusa Tenggara, Kepulauan Jawa Timur, Indonesia. Kesultanan Islam yang pertama di Bima telah diasaskan oleh Sultan Abdul Kahir apabila baginda memeluk Islam pada tahun 1640 masihi. Terdapat banyak penemuan berkaitan mansukrip yang berbahasa Melayu dan Arab telah dihasilkan di Bima sepanjang pemerintahan kesultanan Bima sehinggalah Indonesia bertukar sebagai sebuah Negara Republik. Pemerintah Kabupaten Bima Nusa Tenggara Barat, "Sejarah Bima", laman sesawang Bimakab, dicapai 15 Feb 2017, http://bimakab. go. id/pagessejarah-bima. html.

${ }^{13}$ Mohamed Anuar Omar Din dan Nik Anuar Mahmud, Sejarah Kesultanan Terengganu, 188.
} 
juz' dan tidak dicetak satu jilid keseluruhan mushaf dan ianya disebarkan ke seluruh dunia Islam. Maka tidak hairanlah, masyarakat Islam di Alam melayu ketika itu kebanyakkannya lebih popular dengan jus 'Amma iaitu jus yang ke 30 sahaja berbanding keseluruhan al-Qur' an kerana surah-surahnya pendekpendek dan senang dibaca dan dipelajari.

Perkembangan percetakan di Alam Melayu telah bemula awal abad-19, pada waktu itu kerja-kerja penyalinan al-Qur'an secara manual telah mula berkurangan ${ }^{14}$. Terdapat dua kaedah cetak yang popular iaitu tipografi (cetakan logam) dan litografi (cetakan batu) yang digunakan untuk menyebarkan al-Qur'an kepada umat Islam di Alam Melayu.

Sebuah al-Qur'an cetak batu antara yang terawal dan masih wujud sehingga sekarang ialah mushaf yang dietak pada 20 Ogos 1848 di Palembang hasil kerja penyalinannya oleh Haji Muhammad Azhar bin Kemas Haji Abdullah. Berdasarkan kepada kolofonnya, mushaf ini dicetak dengan menggunakan alat cetak batu Paris Lithographique yang dibeli oleh beliau dari Singapura ${ }^{15}$.

Hal yang sama juga berlaku di Terengganu, keperluan masyarakat untuk memilik al-Qur'an semakin meningkat berbanding dengan kitab-kitab agama yang lain. Oleh yang demikian, al-Qur'an Terengganu mula dicetak pada tahun 1870 di Singapura. Al-Qur'an yang bercetak ini tercatat kolofon penghasilan pada 20 Rabiulawal 1287 bersamaan 20 Jun 1870. Nama penyalin manuskrip ini juga ada tercatat iaitu Abdul Kadir bin Mustaffa dari Terengganu dan dicetak di Lorong Masjid Sultan Ali, Kampung Gelam, Singapura. Sehingga kini, al-Qur'an Terengganu ini dipercayai adalah yang paling awal yang dicetak hasil kepakaran ulama' lokal ${ }^{16}$.

Pengkaji tidak menjumpai setakat ini sebarang sumber yang mengatakan lain-lain tempat termasuk negeri Terengganu terlibat dalam aktiviti percetakan pada abad ke-19 M selain dari negara Singapura. Walaupun begitu, aktiviti ini semakin bertambah maju

\footnotetext{
${ }^{14}$ Lajnah Pentashihan al-Qur'an, Mushaf al-Qur'an di Indonesia (Jakarta: Badan Litbang Agama dan Diklat Kementerian Agama Republik Indonesia, 2011), 22.

${ }^{15}$ Lajnah Pentashihan al-Qur'an, Mushaf al-Qur'an di Indonesia, 22.

${ }^{16}$ Annabel Teh Gallop, "The Spirit of Langkasuka?," 125.
} 
pada akhir abad ke-19 dan seterusnya abad ke-20 apabila muncul beberapa tempat seperti Pulau Pinang, Sumatera Barat, Bandung dan Palembang yang menjalankan aktiviti percetakan ${ }^{17}$.

\section{Pengklasifikasian Manuskrip al-Qur'an Terengganu}

Manuskrip al-Qur'an kebiasaannya tidak mempunyai kolofon atau maklumat berkenaan penulis, tarikh ia dihasilkan dan tempat. Berbeza dengan manuskrip-manuskrip Melayu yang lain, kebanyakannya lengkap kolofon atau paling kurang maklumat penulis ada tercatat pada awal atau akhir halaman. Begitu juga dengan manuskrip al-Qur'an Terengganu, kebanyakannya tidak mempunyai kolofon dan hal ini menyukarkan pengklasifikasian tempat, tarikh dan penulis asal manuskrip tersebut. Ini terjadi kerana penulis manuskrip menganggap bahawa al-Qur'an merupakan kalamullah dan tugas mereka hanyalah menyalin sahaja kitab suci tersebut ${ }^{18}$. Keadaan ini berbeza dengan manuskrip al-Qur'an yang dihasilkan di era kesultanan Islam seperti Mamluk di Mesir, Uthmaniyyah di Turki, Safawiyah di Iran serta Moghul di India yang mana hampir kesemuanya lengkap mempunyai kolofon, sejarah manuskrip serta tokoh-tokoh yang terlibat dalam penulisan manuskrip tersebut ${ }^{19}$.

Walaupun begitu, terdapat beberapa teori yang disokong oleh bukti-bukti kukuh untuk mengklasifikasikan manuskrip al-Qur'an Terengganu. Tiga aspek penting yang telah dijadikan sandaran bagi mengklasifikasikan manuskrip al-Qur'an Terengganu iaitu yang pertama ragam hiasannya, yang kedua ialah sumber kajian yang telah dilakukan oleh beberapa pengkaji termasuk manuskrip al-Qur'an yang mempunyai kolofon tercatat tarikh dan penulis dan yang ketiga ialah catatan sejarah pengembaraan pada abad ke-19. Ulasan atau pandangan ini penting bagi menyokong kuat bahawa manuskrip-manuskrip al-Qur'an yang dikaji adalah manuskrip yang berasal dari Terengganu.

${ }^{17}$ Lajnah Pentashihan al-Qur'an, Mushaf al-Qur'an di Indonesia, 23.

${ }^{18}$ Ali Akbar (Penyelidik, Bayt al-Qur'an \& Muzium Istiqlal, Taman Mini Indonesia Indah, Jakarta), dalam temubual dengan pengkaji, 15 Jun 2012.

${ }^{19}$ Ali Akbar, "Qur'an-Qur'an Istana Nusantara" (prosiding, International Conference on The Holy Quran, Aryaduta Hotel, Jakarta, 30 Ogos-1September 2016). 


\section{Ragam Hiasan iluminasi}

Annabel Teh Gallop ${ }^{20}$ mengatakan bahawa kajian terhadap iluminasi ${ }^{21}$ manuskrip al-Qur'an Terengganu sangat penting untuk diketengahkan. Ini kerana manuskrip ini merupakan yang terbaik yang pernah dihasilkan di Alam Melayu. Beliau telah mengenalpasti 92 buah manuskrip yang beriluminasi gaya pantai timur dan mengklasifikasikan kesemuanya dalam tiga tipologi iaitu Kelantan, Terengganu dan tipologi yang menggabungkan Terengganu dan Patani ${ }^{22}$.

Pengkaji juga membuat perbandingan secara khusus terhadap satu manuskrip al-Qur'an IAMM 2012.13.6 ${ }^{23}$ yang menjadi koleksi terkini di Muzium Kesenian Islam, Kuala Lumpur juga termasuk dalam kajian beliau dan telah mengklasifikasikannya dalam tipologi Manuskrip al-Qur'an Terengganu.

${ }^{20}$ Gaya Pantai Timur adalah hiasan yang terdapat di Kelantan, Terengganu dan Patani. Annabel Teh Gallop (Ketua Kurator,Bahagian Asia Tenggara British Library, London) dalam temubual melalui email dengan pengkaji, 1 Disember 2012.

${ }^{21}$ Iluminasi adalah hiasan yang berada di sekitar teks dimana ianya berfungsi untuk menjelaskan (illuminate) sesuatu teks. Dalam bahasa disebut sebagai tahzib (penyepuhan emas) kerana pada kebiasaannya iluminasi menggunakan warna emas. Hiasan iluminasi ini kebiasaannya juga terdapat di awal surah alFatihah dan awal surah al-Baqarah, pembahagi tengah manuskrip iaitu pada halaman surah al-Isra' dan awal surah al-Kahfi atau pemulaan juz ke-16 dan hiasan pada akhir al-Qur'an iaitu pada surah al-Falaq dan surah al-Nas. Budaya menghias atau mengiluminasi manuskrip al-Qur'an ini berlaku di seluruh wilayah Alam Melayu seperti Acheh, Patani, Terengganu, Filipina Selatan hinggalah ke Ternate.

${ }^{22}$ Annabel Teh Gallop, "The spirit of Langkasuka”, 84.

${ }^{23}$ Manuskrip 2012. 13. 6 ini disimpan, menjadi koleksi dan dimiliki oleh Muzium Kesenian Islam Malaysia, Kuala Lumpur . Berdasarkan dari sumber dari Annabel , manuskrip 2012. 13. 6 ini telah dibeli oleh Tuan Syed Mohamad al-Bukhary pada Oktober 2011 dari sebuah majlis lelongan barang sejarah dan artifak mewah oleh sebuah agensi lelongan yang terkenal di dunia iaitu Christie's yang berpengkalan di England. Pengkaji telah memperolehi gambar dan maklumat awal manuskrip ini melalui email dari beliau pada 1 Disember 2012 iaitu sebelum ianya tiba di Muzium Kesenian Islam Malaysia. Beliau amat tertarik kepada manuskrip ini dan mengharapkan agar pengkaji melakukan kajian lanjut berkenaan manuskrip ini terutamanya pada aspek huraian qira'at. Menurut beliau, manuskrip ini merupakan satu-satunya manuskrip al-Qur'an Terengganu yang mempunyai huraian qira'at yang lengkap dan sempurna fizikalnya. Annabel Teh Gallop (Ketua seksyen Asia Tenggara, British Library, London), dalam temubual dengan pengkaji, 21 Mei 2014. 
Beliau telah menjadikan helaian pembukaan ${ }^{24}$ sebagai asas kepada kajian iluminasi. Antara ciri-ciri manuskrip al-Qur'an Terengganu yang dikenalpasti beliau ialah sebagaimana berikut. ${ }^{25}$

Gambar 1.2. Ciri-ciri Manuskrip al-Qur'an

Terengganu mengikut teori Annabel

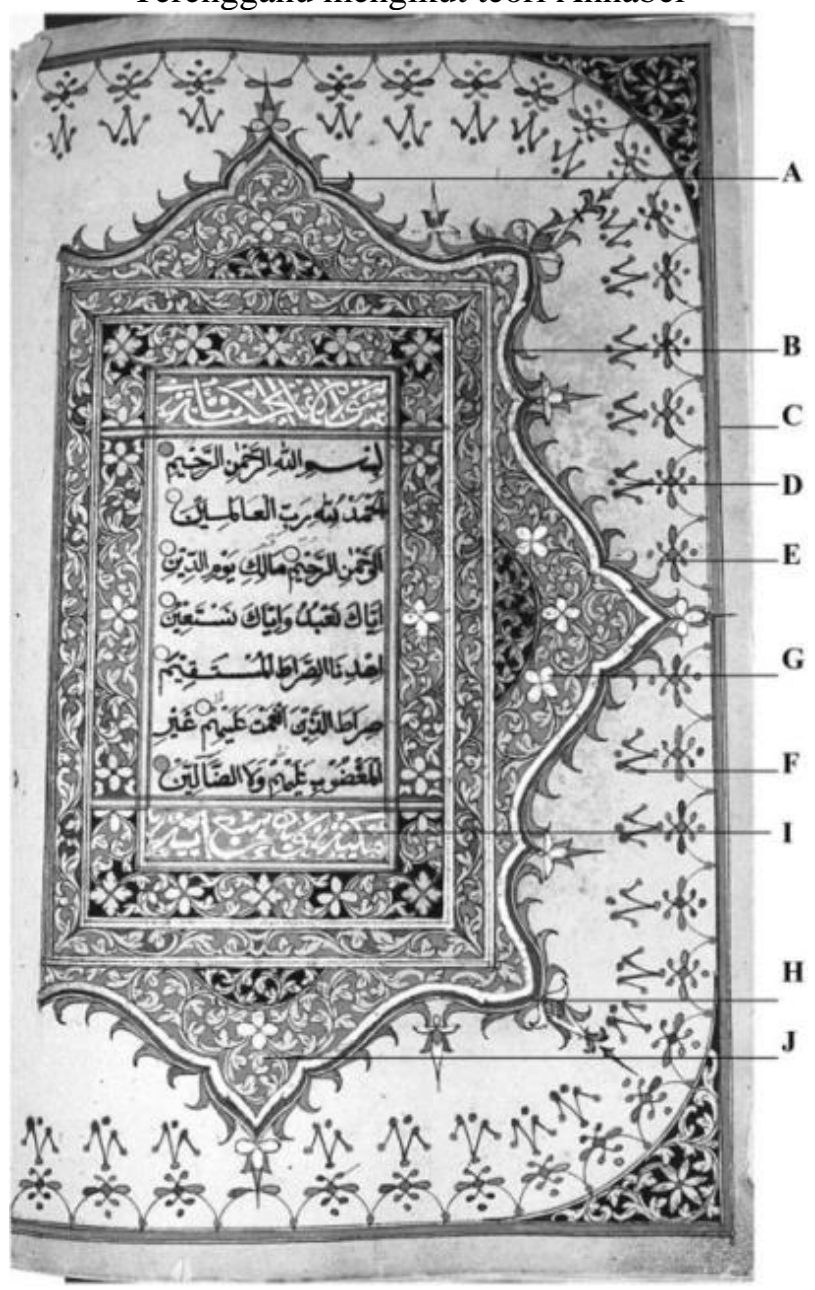

${ }^{24}$ Helaian pembukaan ialah helaian awal yang mengandungi Surah al-Fatihah dan lima ayat awal Surah al-Baqarah. Kebiasaan manuskrip al-Qur'an mempunyai hiasan yang indah pada dua helaian pembukaan ini.

25 Annabel The Gallop, "The Spirit of Langkasuka," 117. 
A.Garis luar lukisan gerbang di bahagian bingkai teks adalah bersambung.

B. Mempunyai corak beralun di atas gerbang.

C. Bingkai hiasan luar mengelilingi bahagian tepi muka surat, berbentuk melengkung di bahagian sudut.

D.Terdapat lukisan berbentuk seperti tombol tajam yang terkeluar dari dinding bingkai luar menghala ke bingkai teks di bahagian dalam yang seolah-olah stalagmite-stalactite.

E. Mempunyai lukisan bentuk separuh bulatan.

F. Corak berbentuk huruf ' $M, W$ '.

G.Terdapat gerbang kecil separuh bulatan di atas puncak gerbang berbentuk bujur.

H.Di kiri dan kanan terdapat dua gerbang yang mengapit gerbang utama dan melekap pada bingkai hiasan teks.

I. Panel kaligrafi yang cantik.

J. Motif flora dan foliate yang berulang-ulang.

Gambar 1. 2. Iluminasi yang terdapat pada

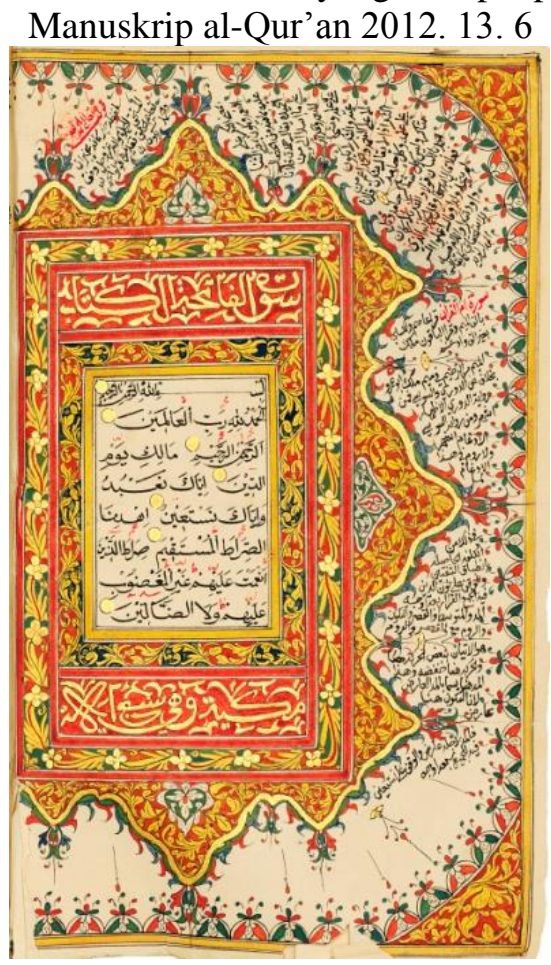


Pandangan beliau dikuatkan lagi dengan kajian yang telah dibuat oleh kurator MKIM terhadap manuskrip ini. Ini kerana MKIM telah meneliti pelbagai aspek sebelum memperolehinya pada tahun 2012. Maklumat mengenai manuskrip yang bernilai telah dimuatkan di dalam buku al-Qur'an; The Sacred Art of Revelation $^{26}$. Di dalam buku ini, Heba Nayel Barakat dan Nurul Iman Rusli mengatakan Manuskrip Qur'an Terengganu IAMM 2012.13. 6 ini adalah antara yang terbaik dan paling indah yang pernah dihasilkan dalam dunia Melayu.

Mereka juga menjelaskan aspek fizikal dan kaedah penjilidan yang mana material dan motif kain yang digunakan adalah sangat berbeza dengan lain-lain manuskrip al-Qur'an. Selain itu kaedah penjilidan yang menggunakan kulit binatang berwarna merah dan dihiasi dengan cop emas mewah adalah antara ciri penting kepada manuskrip dari Pantai Timur khususnya Terengganu.

Berdasarkan kajian mereka, jelas membuktikan manuskrip ini berasal dari Terengganu ${ }^{27}$. Selain itu, huraian qira'at yang terdapat pada bahagian tepi teks al-Qur'an merupakan penemuan baru dalam koleksi manuskrip al-Qur'an Terengganu. Ini kerana ianya sangat jarang ditemui dalam mana-mana manuskrip al-Qur'an yang dihasilkan di Malaysia, namun ianya banyak terdapat pada manuskrip al-Qur'an Banten dan Sulawesi Selatan ${ }^{28}$.

Perbahasan mengenai iluminasi manuskrip al-Qur'an Terengganu ini juga banyak disentuh oleh Ali Akbar ${ }^{29}$. Beliau telah membuat kajian terhadap ciri-ciri iluminasi gaya Terengganu ini dengan memaparkan beberapa manuskrip gaya hiasan ini yang terdapat di beberapa tempat di Indonesia dan juga Malaysia. Antara yang paling terkesan dengan gaya ini ialah manuskrip alQur'an dari kesultanan Bima ${ }^{30}$ yang menjadi koleksi di Bayt al-

${ }^{26}$ Heba Nayel Barakat dan Nurul Iman Rusli, al-Qur'an; The Sacred Art of Revelation (Kuala Lumpur: Islamic Art Museum, 2014), II : 322.

${ }^{27}$ Heba Nayel Barakat dan Nurul Iman Rusli, al-Qur'an; The Sacred Art of Revelation, 323.

${ }^{28}$ Riswadi Azmi, "Mushaf al-Qur'an wa al-Qira'at Bukti Kepakaran Sarjana Melayu Dalam Ilmu Qira'at di Nusantara".

${ }^{29}$ Ali Akbar, 'Qur'an-qur'an Istana Nusantara".

${ }^{30}$ Bima merupakan nama tempat yang terletak di bahagian barat Nusa Tenggara, Kepulauan Jawa Timur, Indonesia. Kesultanan Islam yang pertama di Bima telah diasaskan oleh Sultan Abdul Kahir apabila baginda memeluk Islam pada tahun 1640 masihi. Terdapat banyak penemuan berkaitan mansukrip yang berbahasa Melayu dan Arab telah dihasilkan di Bima sepanjang pemerintahan 
Qur'an dan Muzium Istiqlal, Jakarta. Menurut pandangan beliau, kesultanan Bima mempunyai hubungan yang erat dengan kesultanan Terengganu sehingga Sultan Terengganu mewakafkan manuskrip al-Qur'an tersebut sebagai tanda hubungan diplomasi antara Negara.

Gambar 1. 3. Persamaan ciri-ciri iluminasi yang terdapat manuskrip al-Qur'an Bima yang diwakafkan oleh Kesultanan Terengganu.

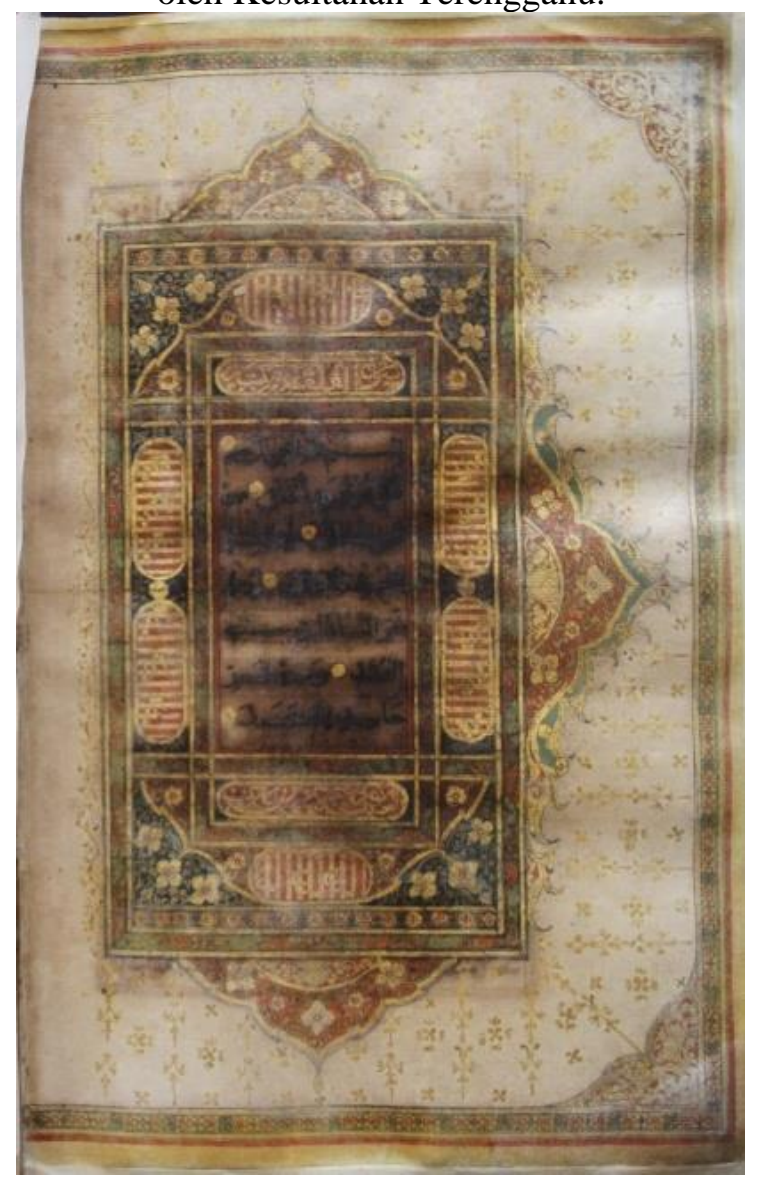

kesultanan Bima sehinggalah Indonesia bertukar sebagai sebuah Negara Republik. Pemerintah Kabupaten Bima Nusa Tenggara Barat, "Sejarah Bima", laman sesawang Bimakab, dicapai 15 Feb 2017, http://bimakab. go. id/pagessejarah-bima. html. 


\section{Sumber Kajian dan Catatan Kolofon}

Penelitian terhadap manuskrip al-Qur'an Terengganu telah dilakukan oleh Perbadanan Muzium Melaka (PMM) dan MKIM. Semasa mencari bahan artifak untuk dipamerkan di MBM, pihak MBM telah meneliti satu manuskrip al-Qur' an yang diperolehinya dari Terengganu.

Selain itu terdapat satu manuskrip IAMM (1998. 1. 3427) yang paling terkenal berasal dari Terengganu telah menjadi koleksi MKIM. Sebelum ini manuskrip tersebut diperolehi dan menjadi koleksi Pusat Islam Malaysia (sekarang JAKIM) sebelum ianya diserahkan kepada MKIM. Catatan kajian Barkeshli dan Mandana ${ }^{31}$ mengatakan bahawa manuskrip al-Qur'an ini berasal dari Terengganu berdasarkan lokasi yang diperolehi oleh Pusat Islam Malaysia dan dihasilkan antara tahun 1793 - 1808 M. Sultan Terengganu yang memerintah pada waktu itu ialah Baginda Sultan Omar. Pengkaji juga ada meneliti manuskrip ini dan terdapat dua halaman akhir yang tercatat jumlah halaman dalam bahasa melayu $^{32}$.

Walaupun hampir semua manuskrip al-Qur'an Terengganu tidak mempunyai kolofon, namun terdapat satu manuskrip alQur'an yang mempunyai kolofon dan ianya menjadi teori penting kepada semua manuskrip al-Qur'an yang mempunyai ciri hiasan iluminasi yang sama ${ }^{33}$. Pandangan ini juga disokong oleh Annabel $^{34}$ apabila beliau telah meneliti satu manuskrip al-Qur'an IAMM 1998.1.3436 yang menjadi koleksi MKIM. Manuskrip ini satu-satunya manuskrip al-Qur'an yang mempunyai kolofon yang mana tercatat tarikh 13 Sya'aban 1275 hijrah bersamaan 18 Mac 1859 M. Selain tarikh ianya dihasilkan, manuskrip ini juga mengandungi nama penulis iaitu Haji Ahmad dan nama tempat iaitu Kampung Menjelagi. Kampung ini terletak di daerah Besut, Terengganu.

${ }^{31}$ Barkeshli dan Mandana, 2002. Islamic Arts Museum Malaysia (Kuala Lumpur: Islamic Arts Museum Malaysia, 2002), 12.

32 Al-Qur'an, no. IAMM 1998. 1. 3427 (folio 511-512), dalam The Islamic Arts Museum Malaysia - Volume 1 (Kuala Lumpur: Islamic Arts Museum Malaysia, 2002).

${ }^{33}$ Ali Akbar (Penyelidik, Bayt al-Qur'an dan Muzium Istiqlal, Jakarta) dalam temubual dengan pengkaji, 1 Ogos 2016.

34 Annabel The Gallop, "The Spirit of Langkasuka?," 116. 


\section{Catatan Sejarah Pengembaraan.}

Catatan sejarah pengembaraan dua orang tokoh penting dalam sejarah sastera Melayu juga antara sumber yang menyokong kepada penghasilan manuskrip al-Qur'an di Terengganu. Abdullah bin Abdul Kadir Munsyi atau dikenali sebagai Munsyi Abdullah telah membuat catatan perjalanan beliau dari Singapura ke Kelantan pada tahun 1254 hijrah bersamaan $1838 \mathrm{M}^{35}$. Terdapat dua aspek penting berkenaan pengajian dan penulisan al-Qur'an yang disentuh beliau sepanjang perjalanan tersebut. Yang pertama ketika beliau tiba di negeri Pahang "seraya ia menyebutkan adanya rumah-rumah untuk belajar mengaji"- kegiatan mengaji adalah "adat dalam segala negeri-negeri Melayu dalam dunia". Pengajian al-Qur'an ini dilakukan sejak kecil lagi. " Semuanya daripada kecilnya ia memulai mengaji al-Qur'an," walaupun" dengan tiada ia mengerti...". Catatan ini menggambarkan bahawa rakyat Pahang ketika itu menjadikan pengajian al-Qur'an sesuatu pembelajaran yang sangat penting.

Semasa beliau tiba di Terengganu. Beliau melihat di Terengganu "ada enam tujuh anak-anak dalam satu-satu rumah mengaji al-Qur'an". Beliau juga membuat catatan tentang kepandaian orang Terengganu dalam menghias manuskrip alQur'an, "kebanyakan terpuji mushaf Terengganu dari negerinegeri yang lain.".

Hal ini dinyatakan juga oleh Annabel ${ }^{36}$ bahawa kenyataan dan catatan dari Abdullah Munsyi ini menjadi sumber penting akan kearifan dan kepakaran masyarakat Terengganu dalam menghias manuskrip al-Qur'an berbanding dengan negeri lain yang dilawatinya. Kisah perjalanan Abdullah bin Abdul Kadir Munsyi ini telah banyak memaparkan tradisi dan pembudayaan alQur'an telah hidup subur di negeri-negeri Melayu pada waktu itu.

Menurut beliau juga, selain Abdullah bin Abdul Kadir Munsyi membuat catatan mengenai manuskrip al-Qur'an Terengganu. Hugh Clifford yang melawat Terengganu pada tahun 1895 telah memuji kepakaran masyarakat Terengganu dalam pengajian al-Qur'an pada waktu itu berbanding dengan negerinegeri jirannya.

\footnotetext{
35 Abdullah Abdul Kdir Munsyi, Kesah Pelayaran Abdoellah bin Abdelkadir Moensji: dari Singapoera sampa ka negeri Kalantan (t. tp.: t.p., 1854), 18.

${ }^{36}$ Annabel Teh Gallop, "The Art of The Malay Quran”, 88.
} 
Seterusnya manuskrip al-Qur'an Terengganu mengalami perkembangan dalam dunia percetakan. Pada tahun 1870 manuskrip al-Qur'an dari Terengganu ini telah dicetak di Singapura. Di dalam versi cetakan ini tercatak kolofon penghasilan pada 20 Rabiul Awwal 1287 bersamaan 20 Jun 1870. Nama penyalin manuskrip ini juga ada tercatat iaitu Abdul Kadir bin Mustaffa dari Terengganu dan dicetak di Lorong Masjid Sultan Ali, Kampung Gelam, Singapura ${ }^{37}$.

Gambar 1.4 Catatan kolofon pada manuskrip al-Qur'an Terengganu yang dicetak di Singapura ${ }^{38}$.

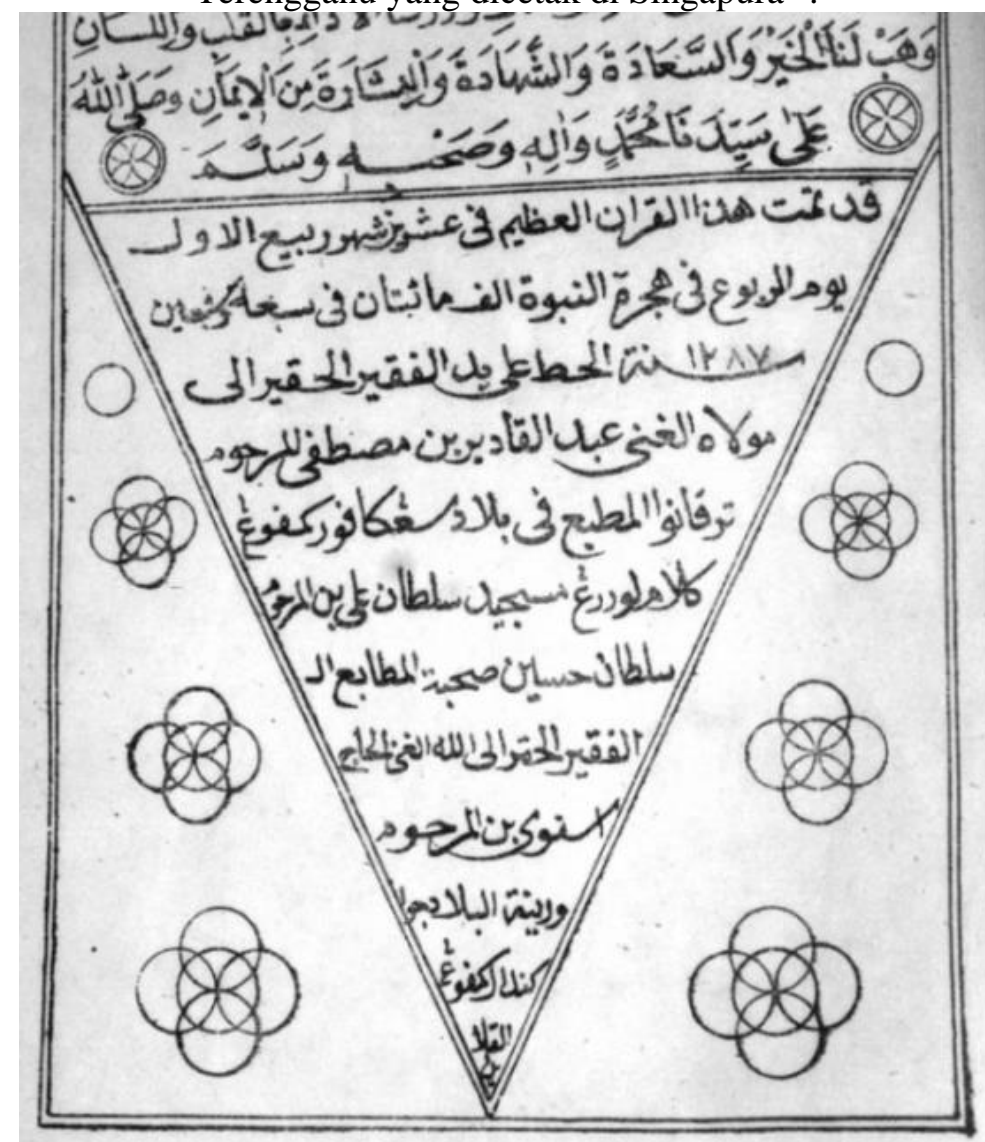

${ }^{37}$ Annabel Teh Gallop,"The Spirit of Langkasuka?," 125

${ }^{38}$ Sumber gambar oleh Annabel Teh Gallop, Kurator British Library. 


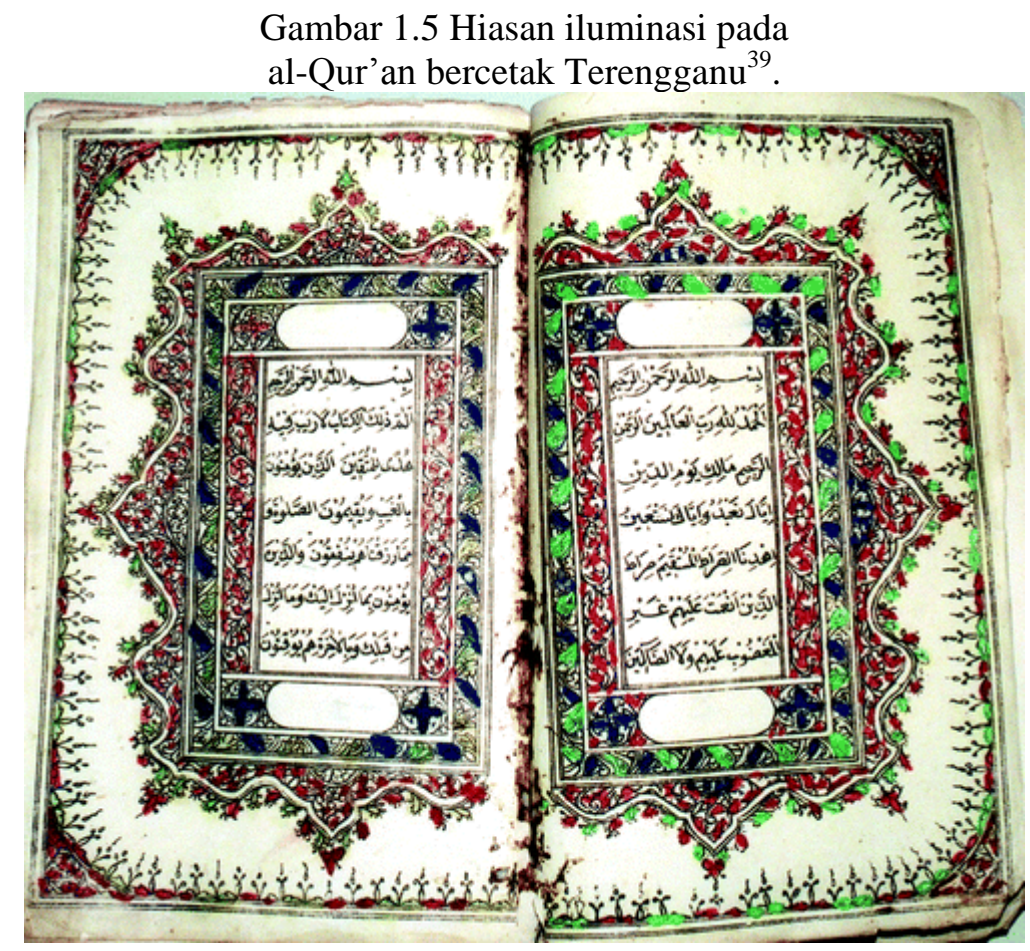

\section{Taburan Manuskrip-manuskrip Al-Qur'an Terengganu}

Usaha untuk memelihara dan mengkoleksi manuskrip Melayu amnya dan manuskrip al-Qur'an khasnya telah bermula semenjak pihak kerajaan merasai pentingnya memelihara, mengkoleksi dan membuat kajian terhadap manuskrip Melayu khasnya manuskrip al-Qur'an. Penubuhan Pusat Manuskrip Melayu (PMM) di Perpustakaan Negara Malaysia pada tahun 1985 dan Muzium Kesenian Islam Malaysia (MKIM) adalah inisitif utama kerajaan untuk menjalankan usaha-usaha pengumpulan dan pemuliharaan manuskrip al-Qur'an. PMM sehingga kini telah menyimpan 40 buah manuskrip al-Qur'an ${ }^{40}$, manakala MKIM pula telah

\footnotetext{
${ }^{39}$ Sumber gambar oleh Annabel Teh Gallop, Kurator British Library.

${ }^{40}$ Faizal Hilmie bin Yusof (Ketua, Pusat Kebangsaan Manuskrip Melayu, Perpustakaan Negara Malaysia), dalam temubual dengan pengkaji, 15 Oktober 2015.
} 
menyimpan lebih dari 20 manuskrip al-Qur'an ${ }^{41}$. Kebanyakan dari koleksi-koleksi manuskrip al-Qur'an ini adalah manuskrip alQur'an yang berciri atau berasal dari Patani dan Terengganu dan sebahagian kawasan dari Asia Tenggara.

Selain daripada dua tempat yang menyimpan koleksi alQur'an yang terbanyak di Malaysia, Muzium Seni Asia, Universiti Malaya juga menyimpan dua buah manuskrip al-Qur'an, namun kedua-duanya adalah berciri dan berasal dari Acheh dan Patani.

Dalam usaha menjejaki manuskrip al-Qur'an Terengganu, pengkaji telah pergi ke beberapa tempat untuk meneliti dan membuat kajian. Maklumat berkenaan lokasi keberadaan manuskrip ini telah diperolehi dari pengkaji-pengkaji manuskrip al-Qur'an Terengganu. Pengkaji akan menyenaraikan sembilan buah manuskrip al-Qur'an Terengganu lengkap 30 juz yang terdapat di beberapa tempat sebagaimana jadual berikut;

Jadual 1.1. Senarai manuskrip al-Qur'an

Terengganu dan maklumat lokasi

\begin{tabular}{|c|l|l|}
\hline Bil. & \multicolumn{1}{|c|}{ Tempat/ lokasi koleksi } & \multicolumn{1}{|c|}{ No. Manuskrip } \\
\hline 1 & Muzium Negara Malaysia & MSN 32. 1992 \\
\hline 2 & Perpustakaan Negara Malaysia & MSS 4136 \\
\hline 3 & \multirow{2}{*}{ Muzium Kesenian Islam, } & IAMM 2012. 13.6 \\
4 & Kuala Lumpur & IAMM 1998. 1. 3436 \\
\cline { 3 - 4 } 5 & & IAMM 1998. 1. 3427 \\
\hline 6 & Muzium Budaya Melaka & PMM 885. 01. U1. 56 \\
\hline 7 & Noorhaiza Noordin & \\
\hline
\end{tabular}

${ }^{41}$ Muhamad Edzhar Bin Muhamad Razali (Eksekutif Kanan bahagian Rekod dan Koleksi Eksklusif, Muzium Kesenian Islam Malaysia), dalam temubual dengan pengkaji, 27 Januari 2017.

42 Noorhaiza Noordin, beliau merupakan seorang pengukir kayu terkenal dari Besut, Terengganu. Beliau banyak menghasilkan seni ukiran kayu yang menghiasi banggunan ikonik Negara dan luar Negara seperti Istana Melawati, Putrajaya, Brunei Gallery, London dan Oxford Centre of Islamic Studies, UK. Beliau mempunyai sebuah manuskrip al-Qur'an Terengganun dan menjadikannya koleksi berharga milik beliau. "Penulis tidak diketahui", Langkasuka, Sacred \& Profane (Kuala Lumpur: Akademi Nik Rashiddin, t.t.), 3. 


\begin{tabular}{|c|l|c|}
\hline Bil. & \multicolumn{1}{|c|}{ Tempat/ lokasi koleksi } & No. Manuskrip \\
\hline 8 & $\begin{array}{l}\text { Bayt al-Qur'an dan Muzium } \\
\text { Istiqlal, Jakarta }\end{array}$ & BQMI 1.1.1 \\
\hline 9 & $\begin{array}{l}\text { Pesantren Popongan, } \\
\text { Surakarta, Jawa Tengah }^{44}\end{array}$ & \\
\hline
\end{tabular}

Di antara sembilan manuskrip yang disenaraikan, ada beberapa manuskrip yang tidak dapat pengkaji menelitinya dengan sendiri namun pengkaji memperolehi maklumat dari pengkajipengkaji lain melalui medan seminar dan konvensyen yang disertai.

\section{Manuskrip Al-Qur'an MN 32. 1992}

Manuskrip ini antara manuskrip al-Qur'an yang menjadi koleksi di Muzium Negara dan antara manuskrip awal yang menjadi koleksi muzium ini serta sering menjadi bahan kajian kepada pengkaji manuskrip al-Qur'an Alam Melayu. Manuskrip yang lengkap dan sempurna ini mempunyai ukuran folio $40 \times 30 \mathrm{~cm}$ dan ianya antara manusrip al-Qur'an Terengganu yang mempunyai saiz yang kedua terbesar selepas manuskrip al-Quran IAMM 1998.1.3427 yang berukuran 43 x $28 \mathrm{~cm}$. Manuskrip ini mempunyai halaman pembukaan, halaman tengah dan halaman akhir yang beriluminasi indah. Ianya menggunakan warna merah, kuning, hijau, unggu, biru dan berperada emas. Ianya tidak mempunyai kolofon, namun Annabel mengkelaskannya dengan ciri-ciri yang sama dengan manuskrip al-Qur'an Terengganu yang lain seperti IAMM 1998.1.3436 dan IAMM 1998.1. 3427 yang menjadi koleksi di $\mathrm{MKIM}^{45}$.

${ }^{43}$ Bayt al-Qur'an dan Muzium Istiqlal adalah merupakan tempat pengumpulan dan kajian mushaf al-Qur'an. Didirikan pada tahun 1995, tempat ini juga menjadi pusat rujukan kepada rakyat Republik Indonesia untuk mendalami ilmu al-Qur'an. H. Muchlis et al. , Bayt al-Qur'an \& Museum Istiqlal (Indonesia: Lajnah Pentashihan Mushaf al-Qur'an dan Diklat Kementerian Agama RI, 2015), 5.

${ }^{44}$ Manuskrip al-Qur'an ini adalah milik Raden Mas Tumenggung Wiryadingrat (wafat 1971). Manuskrip ini berada koleksi Pesantren al-Manshur, Popongan, Klaten, Jawa Tengah. Ukuran manuskrip ini ialah 39 x $2.5 \mathrm{~cm}$ dan masih dalam keadaan baik. Islah Gusmian, "Karakteristik Mushaf al-Qur'an Kuno", 114-116

${ }^{45}$ MKIM adalah singkatan kepada Muzium Kesenian Islam Malaysia. 
Gambar 1.19 Hiasan iluminasi yang terdapat manuskrip al-Qur'an MN 32.1992

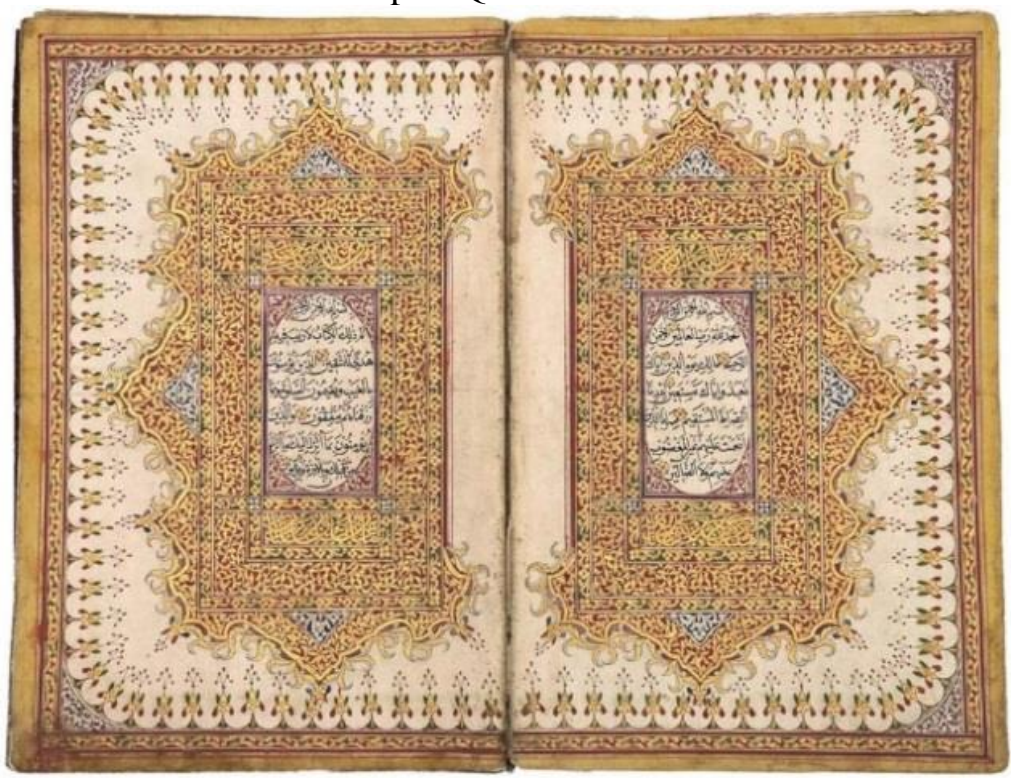

\section{Manuskrip Al-Qur'an MSS 4136}

Manuskrip al-Qur'an lengkap ini menjadi koleksi di Perpustakaan Negara Malaysia. Ianya mempunyai keunikan yang tersendiri kerana satu-satunya manuskrip al-Qur'an Terengganu yang dipecahkan kepada 4 jilid. Jilid satu mengandungi surah al-Fatihah sehingga surah al-'An'ām, jilid kedua mengandungi surah al-'Araf sehingga surah al-Nahl, jilid ketiga pula mengandungi surah alIsrā' sehingga Yasin dan jilid yang keempat mengandungi surah al-Ṣaffăt sehingga surah al-Nās. Sepanjang penelitian pengkaji, pengkaji belum pernah melihat manuskrip Qur'an dari Alam Melayu yang lain mempunyai pecahan 4 jilid seperti ini. Manuskrip yang berukuran $12 \mathrm{~cm}$ panjang dan $8 \mathrm{~cm}$ lebar ini mempunyai langkau baris 15 dan mempunyai 603 halaman kesemuanya. Kulit manuskrip ini agak berbeza dengan manuskrip al-Qur'an Terengganu yang lain kerana kebiasaannya menggunakan kulit haiwan berwarna merah dan berperada emas, manakala manuskrip in hanya menggunakan kain berwarna hitam tanpa sebarang hiasan. Jika dilihat pada aspek hiasan iluminasinya yang terdapat pada halaman pembukaan, secara jelasnya ianya 
mempunyai ciri-ciri hiasan dari Terengganu ${ }^{46}$. Warna-warna yang digunakan ialah merah, biru, kuning dan sedikit warna hijau serta mempunyai perada emas yang agak sederhana. Begitu juga kaligrafinya pula agak sederhana berbanding dengan lain-lain manuskrip al-Qur'an Terengganu yang agak baik tulisannya. Walaupun begitu manuskrip ini masih menggunakan jenis tulisan Naskh. Keunikan lain yang terdapat padanya juga ialah manuskrip ini mempunyai beberapa huraian tambahan di luar teks al-Qur'an iaitu catatan huraian qira'at berbahasa Melayu penerangan wakaf dalam bahasa Arab. Kedua-dua huraian tambahan ini hanyalah sedikit dan terletak pada halaman-halaman pilihan sahaja dan huraian tentang wakafnya lebih banyak berbanding dengan huraian qira'atnya. Manuskrip ini mempunyai catatan kolofon tarikh siap penulisannya iaitu pada 19 Ramadhan 1252 hijrah bersamaan 27 Disember $1836 \mathrm{M}^{47}$.

Gambar 1.21 Halaman pembukaan dan catatan qira'at berbahasa Melayu dan huraian wakaf yang terdapat pada MSS4136.

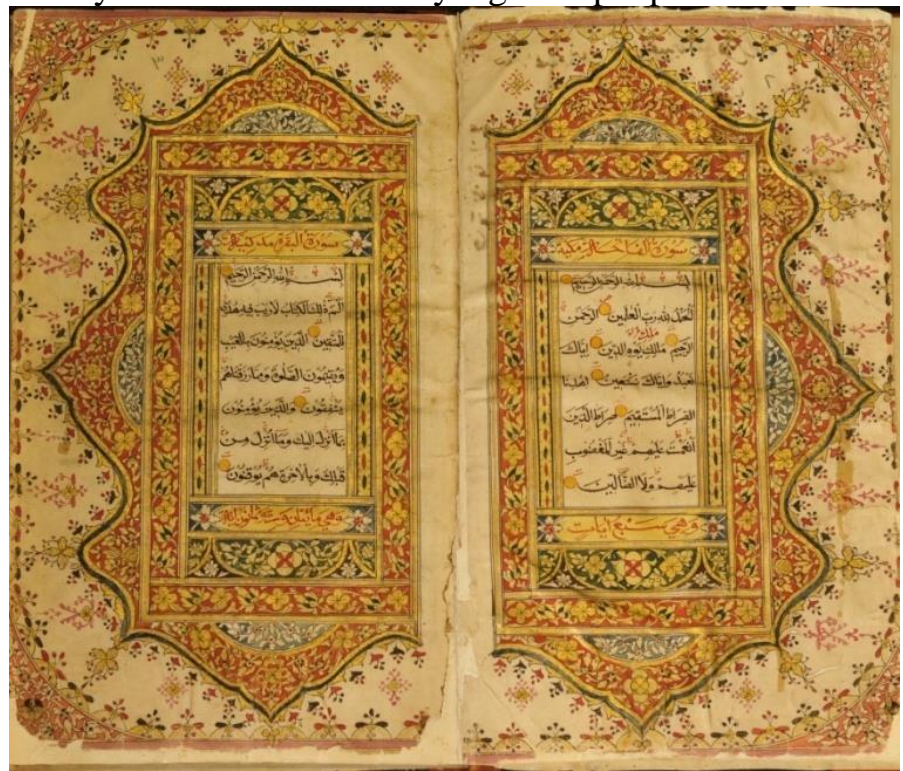

${ }^{46}$ Al-Qur'an, no. MSS 4136 (folio 2-3), Kuala Lumpur, Perpustakaan Negara Malaysia.

${ }^{47}$ Al-Qur'an, no. MSS 4136 (folio 603), Kuala Lumpur, Perpustakaan Negara Malaysia. 

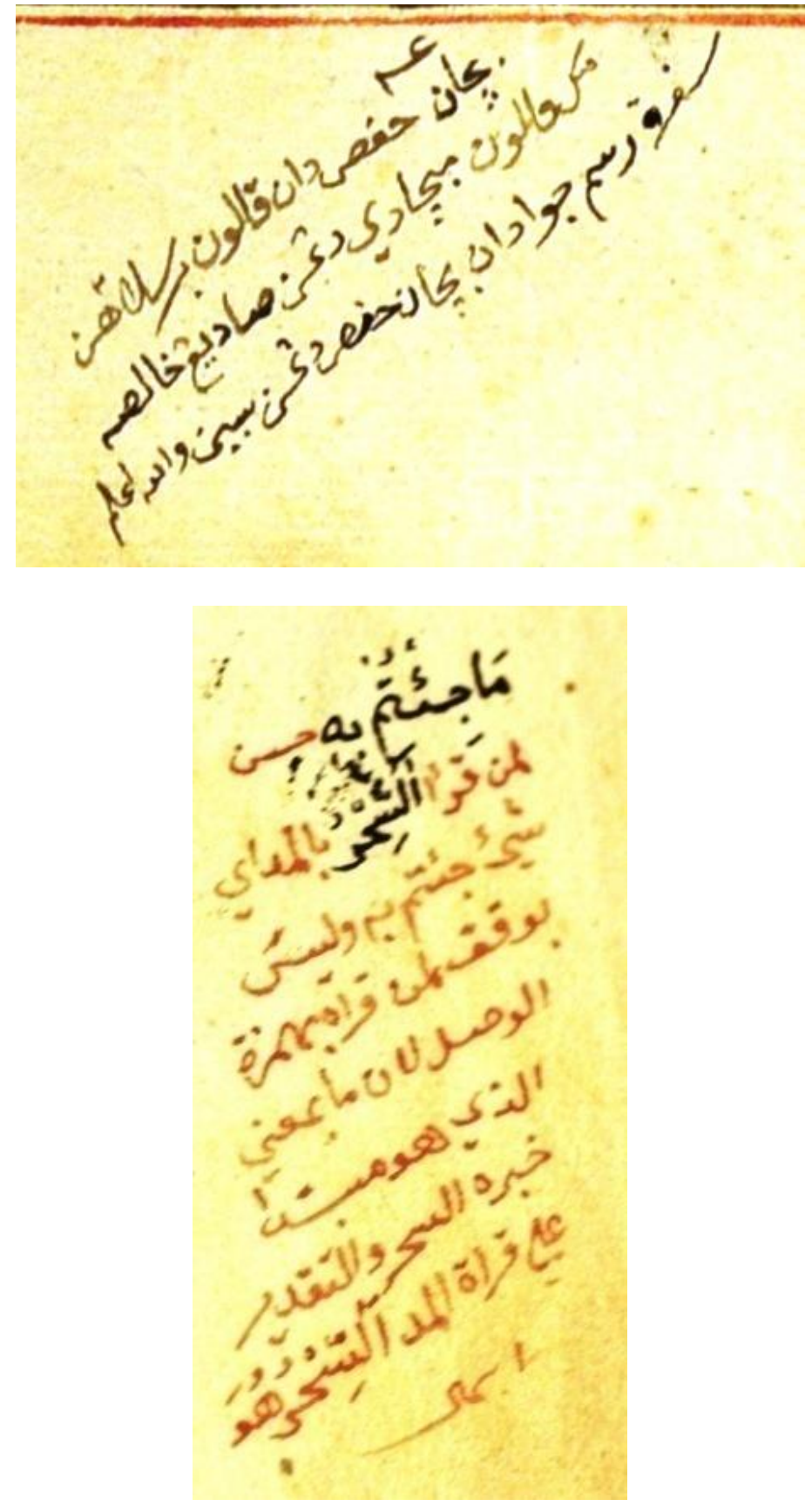


\section{Manuskrip Al-Qur'an IAMM 2012. 13. 6}

Manuskrip al-Qur'an ini menjadi koleksi di Muzium Kesenian Islam Kuala Lumpur. Manuskrip ini adalah antara yang terbaik di antara manuskrip al-Qur'an Terengganu yang lain. Pengkaji mengatakan demikian kerana manuskrip ini mempunyai huraian tambahan qira'at yang lengkap, kaligrafinya yang kemas, hiasan iluminasinya yang indah dan berperada emas yang mewah dan menyerlah. Manuskrip al-Qur'an yang dikaji ini mempunyai kondisi fizikal yang sangat baik. Maka tidak hairanlah MKIM berusaha untuk memperolehinya kerana nilai hiasan, kandungan teks serta aspek lokal yang terdapat di dalamnya. Manuskrip ini disimpan rapi oleh Muzium Kesenian Islam Malaysia, Kuala Lumpur dan dipamerkan di bahagian Galeri Alam Melayu. Mempunyai ukuran folio 320 x 209 mm, manakala ukuran ruangan teks ialah $215 \times 120 \mathrm{~mm}$. Saiz manuskrip ini ialah saiz biasa bagi lain-lain manuskrip al-Qur'an Terengganu yang lain. Saiz manuskrip al-Qur'an Terengganu yang terbesar yang pernah dijumpai pengkaji ialah IAMM 1998. 1. 3427. Saiz ukuran folionya ialah $432 \times 280 \mathrm{~mm}$.

\section{Manuskrip al-Qur'an IAMM 1998. 1. 3436}

Al-Qur'an ini adalah antara manuskrip al-Qur'an Terengganu yang penting kepada pengkaji-pengkaji manuskrip al-Qur'an Terengganu. Ini kerana di samping ciri-ciri Terengganu yang terdapat pada hiasan iluminasinya, ia juga mengandungi catatan kolofon yang terdapat pada halaman akhir yang bertulis;

Khatam menyurat Qur'an daripada waktu zohor daripada Arba'a daripasa tiga belas bulan Sya'ban daripada hijrat Nabi Salla Allah 'Alayhi wa Sallam seribu dua ratus tujuh puluh lima pada tahun da tahun Haji Ahmad yang menyurat dia fakir yang sangat tua duduk di Kampung Manjelagi tamat kalam bi al-Khair wa Salam ${ }^{48}$.

Mengikut kepada catatan ini, manuskrip ini sempurna penulisannya pada 13 Syaban 1275 bersamaan 18 Mac 1859 M dan ditulis oleh Haji Ahmad. Barkeshi $(2002)^{49}$ mencatatkan

${ }^{48}$ Al-Qur'an, no. IAMM 1998. 1. 3436 (folio 603), Kuala Lumpur, Muzium Kesenian Islam Malaysia.

${ }^{49}$ Barkeshli et al., Nur al-Qur'an (Kuala Lumpur: Muzium Kesenian Islam Malaysia, 1999) 180. 
bahawa manuskrip ini dihasilkan ketika pemerintahan Sultan Zainal Abdin II, sultan Terengganu yang ketiga (1794-1808), namun berdasarkan tarikh yang tercatat pada kolofon, jelasnya ia dihasilkan ketika pemerintahan Baginda Sultan Omar (1831, 18391876). Manuskrip yang bersaiz besar iaitu $28 \mathrm{~cm}$ panjang dan 21 $\mathrm{cm}$ lebar ini mempunyai langkau baris 15 . Ianya menjadi koleksi di Muzium Kesenian Islam Malaysia dan terdapat sedikit kerosakan pada manuskrip ini, namun teksnya masih lengkap dan jelas untuk diteliti. Menggunakan warna biasa yang terdapat pada ciri-ciri warna manuskrip al-Qur'an Terengganu iaitu merah, kuning, biru dan sedikit warna hijau serta berperada emas yang agak menyerlah. Kaligrafinya yang menggunakan warna hitam dan khat jenis naskh ini agak sederhana penulisannya.

Gambar 1. 22 Hiasan iluminasi yang terdapat pada IAMM 1998. 1. 3436.

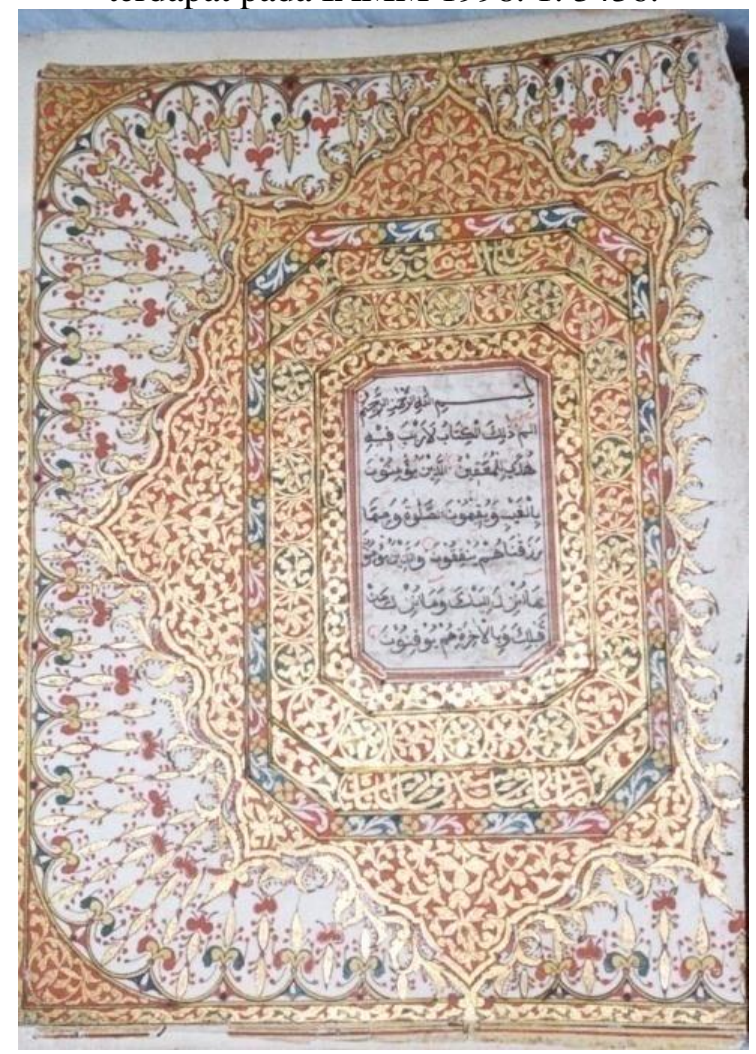




\section{Manuskrip al-Qur'an IAMM 1998. 1. 3427}

Manuskrip ini juga menjadi koleksi di Muzium Kesenian Islam Malaysia. Manuskrip yang bersaiz $43 \mathrm{~cm}$ panjang dan $28 \mathrm{~cm}$ lebar ini adalah yang terbesar saiznya dalam kelas manuskrip al-Qur'an Terengganu yang kebiasaannya mempunyai ukuran $32 \times 21 \mathrm{~cm}$. Manuskrip yang lengkap ini mempunyai hiasan iluminasi yang bercirikan hiasan gaya Terengganu ${ }^{50}$ antara manuskrip al-Qur'an Terengganu yang paling banyak menggunakan perada emas sebagai unsur hiasannya selain dari warna merah, hijau dan kuning.

Oleh kerana hiasan emasnya yang banyak, penulis manuskrip ini membiarkan dua halaman kosong di belakang halaman pembukaannya supaya hiasannya tidak menjejaskan halaman yang mempunyai teks al-Qur'an. Tulisan kaligrafinya yang menggunakan jenis khat naskh ini amat kemas dan bagus strukturnya. Ianya dijilid dengan menggunakan kulit binatang yang diwarnakan merah dan mempunyai perada emas. Sebagaimana ciri-ciri biasa pada al-Qur'an Terengganu, selain daripada hiasan yang terdapat pada halaman pembukaan, terdapat juga hiasan iluminasi pada halaman tengah yang mengandungi surah al-Kahfi ${ }^{51}$ dan juga halaman akhir yang mengandungi surah al-Falaq $^{52}$ dan surah al-Nas. Pada halaman penutup teks al-Qur'an, terdapat jadual yang mengandungi kod-kod yang merujuk kepada sembilan jenis wakaf seperti huruf mim alamat kepada wakaf lazim, huruf tho' merujuk kepada wakaf muthlak dan sebagainya.

Di akhir jadual, iaitu di bawah jadual ini tercatat tarikh ianya selesai ditulis pada 1288 hijrah bersamaan $1872 \mathrm{M}^{53}$. Tarikh ini juga menunjukkan bahawa al-Qur'an ini dihasilkan ketika pemerintahan Baginda Sultan Omar.

${ }^{50}$ Annabel Teh Gallop, "The spirit of Langkasuka?, 120.

${ }^{51}$ Al-Qur'an, no. IAMM 1998. 1. 3427(folio 303), Kuala Lumpur, Muzium Kesenian Islam Malaysia.

${ }^{52}$ Al-Qur'an, no. IAMM 1998. 1. 3427(folio 603), Kuala Lumpur, Muzium Kesenian Islam Malaysia.

${ }^{53}$ Al-Qur'an, no. IAMM 1998. 1. 3427 (folio 611), Kuala Lumpur, Muzium Kesenian Islam Malaysia. 
Gambar 1. 23 Hiasan iluminasi yang terdapat pada IAMM 1998. 1. 3427.

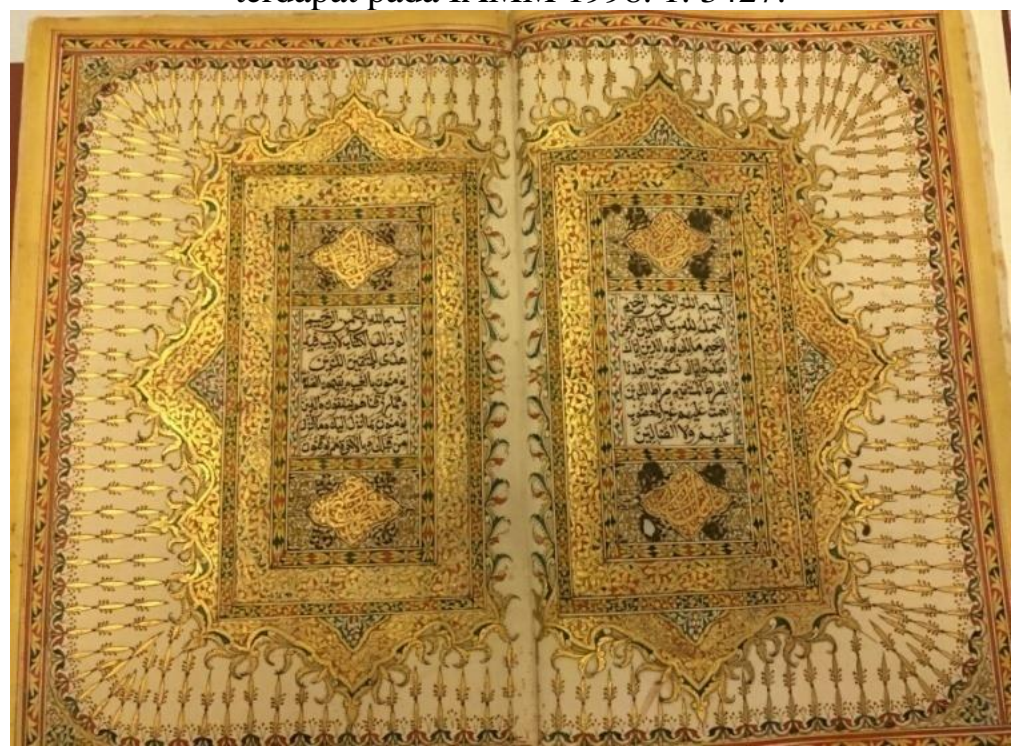

\section{Manuskrip Al-Qur'an PMM 885. 01. U1. 56}

Manuskrip ini menjadi koleksi di Perbadanan Muzium Melaka dan ditempatkan Muzium Budaya Melaka. Manuskrip yang bernombor PMM885. 01. U1. 56 ini mempunyai saiz folionya $33 \times 23 \mathrm{~cm}$ iaitu saiz yang lazim pada manuskrip al-Qur'an Terengganu. Manuskrip ini mempunyai hiasan iluminasi yang indah dan sangat teliti lukisan hiasannya. Warna yang digunakan adalah merah, kuning, biru dan hijau sebagai pelengkap kepada hiasan iluminasinya $^{54}$. Al-Qur'an ini juga menggunakan perada emas yang mewah, iaitu antara ciri-ciri penting yang terdapat pada manuskrip al-Qur'an Terengganu. Kaligrafinya tidaklah sebegitu baik berbanding dengan kekemasan kaligrafi yang terdapat pada manuskrip al-Qur'an Terengganu yang lain, namun ianya masih lagi menggunakan kaligrafi jenis naskh. Manuskrip ini juga menggunakan jilid daripada kulit binatang berwarna merah dan berperada emas. Antara kelainan manuskrip ini ialah terdapat inskripsi pada jilidnya yang tercatat kalimah Allah, berbanding

\footnotetext{
${ }^{54}$ Al-Qur'an, no. PMM 885. 01. U1. 56 (folio 2 dan 3), Melaka, Muzium Kebudayaan Melaka.
} 
manuskrip al-Qur'an Terengganu yang lain tercatat ayat ke 79 dari surah al-Waqiah.

Gambar 1. 25Hiasan iluminasi yang terdapat pada Manuskrip al-Qur'an PMM 885. 01. U1. 56.

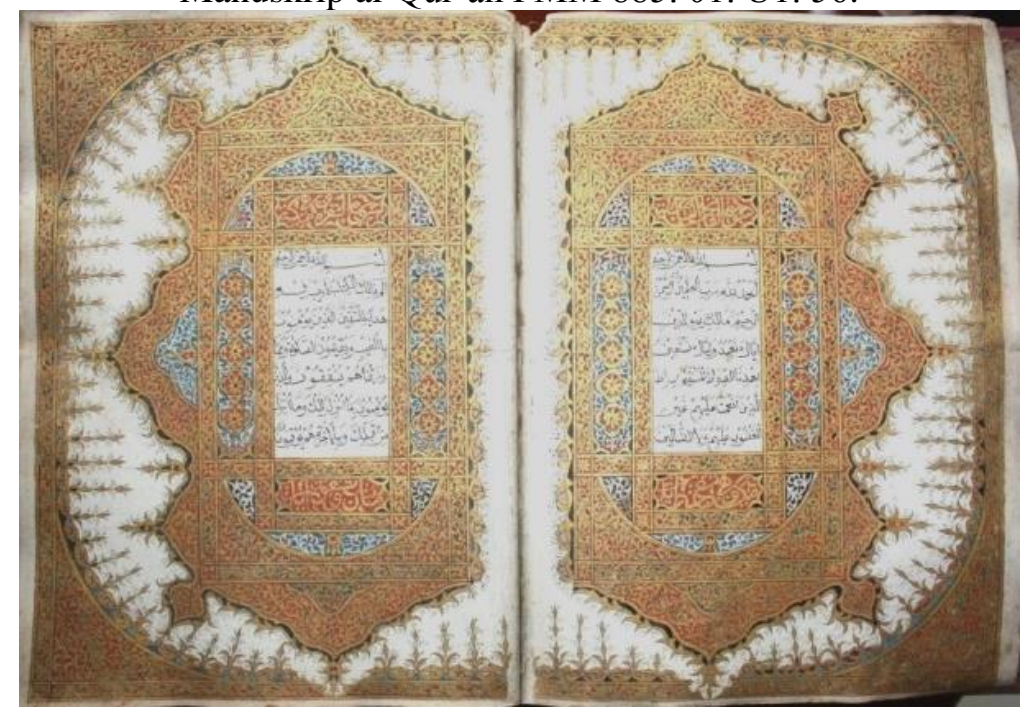

\section{Manuskrip al-Qur'an Koleksi Norhaiza Nordin}

Manuskrip al-Qur'an ini antara manuskrip al-Qur'an Terengganu yang terdapat pada koleksi peribadi. Pemilik manuskrip ini ialah Norhaiza Nordin iaitu seorang pengukir kayu terkenal tanah air. Manuskrip yang mempunyai saiz folio $33 \times 23 \mathrm{~cm}$ ini mempunyai tiga halaman utama yang mempunyai hiasan iluminasi, iaitu halaman pembukaan yang mengandungi surah al-Fātihah dan awal surah al-Baqarah, halaman tengah yang mengandungi awal surah al-Isrā' dan halaman penutup yang mengandungi empat surah yang bermula dengan surah al-Mā'ūn, surah al-Kawthar, surah alKāfirūn dan surah al-Nashr yang berada di sebelah kanan. Di bahagian sebelah kiri pula terdapa tempat surah yang dimulai surah al-Lahab, surah al-Ikhlas, surah al-Falaq dan surah al-Nās ${ }^{55}$. Halaman penutup ini agak berbeza dari kebiasaan manuskrip alQur'an Terengganu kerana kebiasaannya hanya memuatkan dua surah akhir sahaja. Hiasan iluminasinya menggunakan warna

55 Al-Qur'an, (folio 614 dan 615), Terengganu, Seni Ukir Bakawali. 
merah, kuning, hijau dan berperada emas. Kilauan emasnya sangat menyerlah bukan sahaja terdapat pada tiga halaman utamanya bahkan digunakan juga pada tanda wakaf.

Gambar 1.26 Hiasan iluminasi yang terdapat pada Manuskrip al-Qur'an Koleksi Norhaiza Nordin.

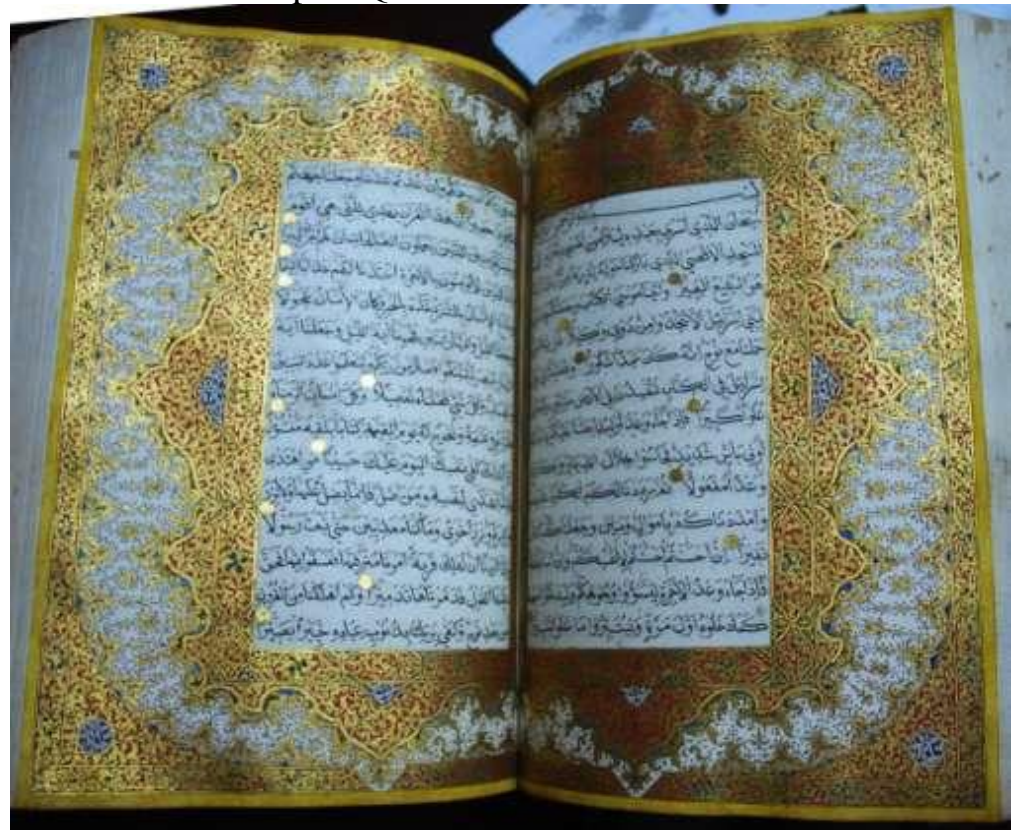

\section{Manuskrip Al-Qur'an BQMI 1.1.1}

Manuskrip al-Qur'an ini antara yang terdapat diluar dari Malaysia, lawatan pengkaji ke Bayt al-Qur'an dan Muzium Istiqlal, Jakarta pada 2013 adalah secara khusus untuk meneliti manuskrip ini dengan lebih dekat. Hasil penelitian dan temubual dengan penyelidik di sana, manuskrip ini telah diwakafkan oleh Hajah Siti Maryam Rakhmat Shalahuddin iaitu Puteri Sultan Muhammad Shalahuddin, Sultan yang memerintah Bima, Indonesia ${ }^{56}$. Mushaf yang dikenali dengan nama Mushaf La Lino yang bermaksud berkilau ini adalah hadiah daripada Kesultanan Terengganu kepada Kesultanan Bima pada abad ke 19 yang mana negeri

${ }^{56}$ Ali Akbar (Penyelidik, Bayt al-Qur'an \& Muzium Istiqlal, Taman Mini Indonesia Indah, Jakarta), dalam temubual dengan pengkaji, 15 Jun 2012. 
Terengganu pada waktu itu terkenal sebagai penghasil mushaf alQur'an beriluminasi indah di Nusantara ${ }^{57}$. Manuskrip yang bersaiz $35 \mathrm{~cm}$ panjang dan $22 \mathrm{~cm}$ lebar ini adalah saiz biasa ciri-ciri alQur'an Terengganu. Warna yang digunakan adalah merah, kuning, hitam dan berperada emas. Keadaan fizikalnya semakin rosak kerana kesan karbon dakwat yang digunakan untuk menulis teks al-Qur'an.

Gambar 1.24 Hiasan iluminasi yang terdapat pada BQMI 1. 1. 1.

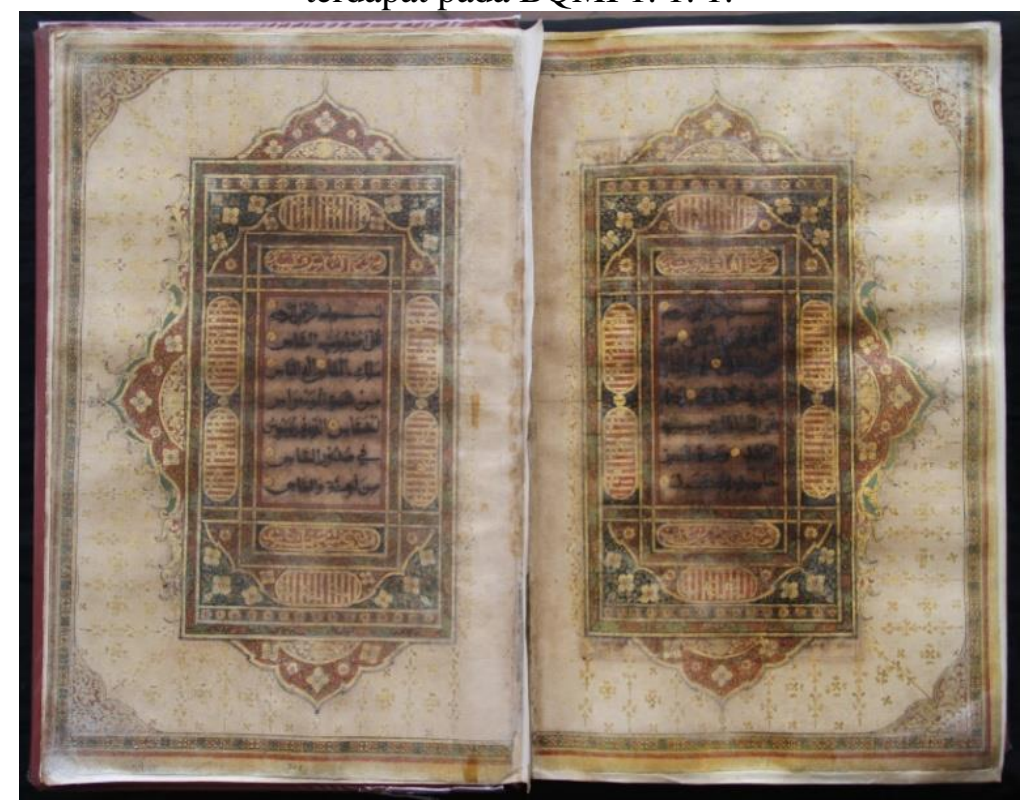

\section{Manuskrip Al-Qur'an Pesantren Popongan, Surakarta, Jawa Tengah}

Manuskrip al-Qur'an ini adalah antara manuskrip Terengganu yang berada di luar Malaysia. Pengkaji belum berkesempatan melihat manuskrip secara dekat, namun maklumat mengenainya telah diperolehi ketika dijemput membentangkan kertas kerja di Jakarta pada tahun 2016. Kajian berkenaannya telah dilakukan

${ }^{57}$ Ali Akbar et al., Khazanah Mushaf al-Qur'an Nusa Tenggara Barat (Jakarta: Lajnah Pentashihan al-Qur'an, 2016), 2. 
oleh Islah Gusmian (2016) ${ }^{58}$ seorang pengkaji yang banyak melakukan kajian terhadap manuskrip al-Qur'an di Indonesia. Kertas kerja beliau adalah secara khusus terhadap manuskrip alQur'an yang menjadi koleksi di Pesantren al-Manshur, Popongan, Surakaarta, Jawa Tengah, Indonesia. Selain al-Qur'an ini, terdapat beberapa manuskrip tulisan tangan dan bercetak menjadi koleksi di Pesantren yang diasaskan oleh Kiai Haji Muhamad Manshur (1858-1955) pada tahun 1926 M. Terdapat catatan luar teks mengatakan bahawa, manuskrip ini dimiliki oleh Raden Mas Tumenggung Wiryadiningrat (w. 1917) seorang yang berpengaruh pada zamannya ${ }^{59}$. Manuskrip yang lengkap dan sempurna ini mempunyai ukuran folionya $39 \mathrm{~cm}$ panjang dan $24.5 \mathrm{~cm}$ lebar, manakala ukuran teksnya ialah 26 x $15 \mathrm{~cm}$. Mempunyai 616 mukasurat dan langkau baris sebanyak 15 baris. Manuskrip ini tidak mempunyai kolofon, namun beliau mengandaikan bahawa ianya dihasilkan sekitar tahun 1820 ke atas berdasarkan bacaan watermark atau tera air yang digunakan untuk menulis manuskrip ini $^{60}$. Islah Gusmian menyebut bahawa, penelitian beliau terhadap ciri-ciri manuskrip al-Qur'an ini adalah mirip dengan ciri-ciri manuskrip al-Qur'an Terengganu dan beliau tidak menolak kemungkinan besar al-Qur'an ini dihasilkan di Terengganu atau ianya adalah hadiah dari Kesultanan Terengganu atas dasar hubungan diplomatik antara dua negara ${ }^{61}$. Kaligrafinya agak sederhana berbanding dengan manuskrip al-Qur'an Terengganu yang lain, namun strukturnya masih jelas dan masih boleh dibaca dengan baik.

${ }^{58}$ Islah Gusmian, "Karakteristik Mushaf al-Qur'an Kuno Koleksi Pesantren alMansur", 109-132.

${ }^{59}$ Islah Gusmian, "Karakteristik Mushaf al-Qur'an Kuno Koleksi Pesantren alMansur”, 118.

${ }^{60}$ Islah Gusmian, "Karakteristik Mushaf al-Qur'an Kuno Koleksi Pesantren alMansur”, 114.

${ }^{61}$ Islah Gusmian (Pensyarah di Universitas Islam Negeri, Sunan Kalijaga, Yogyakarta, Indonesia), dalam temubual dengan pengkaji, 1 September 2016. 
Gambar 1. 25 Hiasan pada halaman permulaan manuskrip al-Qur'an Pesantren al-Manshur, Popongan, Jawa Tengah, Indonesia. ${ }^{62}$

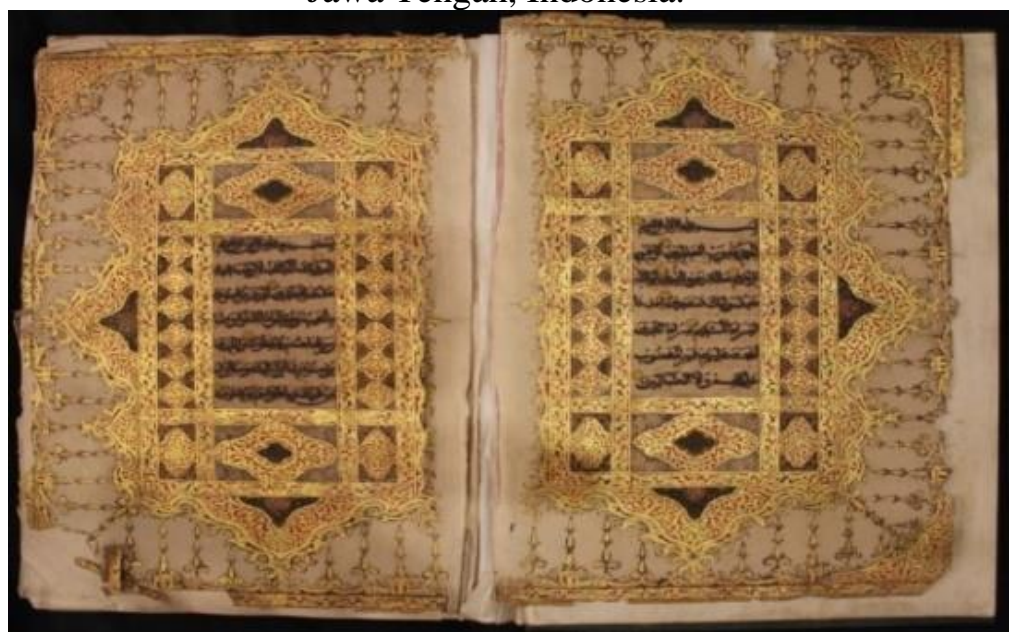

\section{Penutup}

Sejarah penulisan al-Qur'an telah bermula sejak wahyu diturunkan kepada Nabi Muhammad SAW. Ianya diteruskan oleh Abu Bakar dan usaha lebih sistematik diusahakan oleh Uthman al-'Affan. Penulisan al-Qur'an dalam sejarah empayar Islam juga tercatat sebagai satu kewajipan utama kepada Khalifah, Sultan dan pemerintah. Usaha ini amat perlu kerana penulisan al-Qur'an adalah satu kerja yang memerlukan kepada kepakaran dari pelbagai disiplin ilmu dan juga kos penghasilannya yang tidak mampu diusahakan oleh individu.

Zaman empayar seperti Mughal, Safaviyah, Mamluk dan Uthmaniyah antara zaman yang banyak menghasilkan manuskrip al-Qur'an yang kebanyakkanya masih berada dalam keadaan baik dan lengkap. Begitu juga di Alam Melayu, kesultanan Banten, Cirebon, Yogyakarta, Surakarta, Riau-Lingga, Terengganu, Sumbawa, Bima, Bone dan Ternate antara kesultanan yang mempunyai koleksi manuskrip al-Qur'an yang lebih dari satu manuskrip. Kesemua manuskrip al-Qur'an ini tidak hanya berada di negeri-negeri tersebut sahaja, bahkan ada sebahagiannya yang

${ }^{62}$ Islah Gusmian, “Karakteristik Mushaf al-Qur'an Kuno Koleksi Pesantren alMansur”, 117. 
sudah bergerak merentasi sempadan hasil dari kesan penjajahan, geopolitik, asimilasi seni dan budaya.

Lawatan pengkaji ke beberapa tempat dalam dan luar Negara telah menemukan beberapa manuskrip al-Qur'an, namun disebabkan kajian pengkaji tertumpu kepada manuskrip al-Qur'an Terengganu, maka pengkaji telah melimitasikan penelitian terhadap skop tersebut sahaja. Namun begitu pengkaji juga melihat al-Qur' an yang lain sebagai bahan perbandingan.

Manuskrip al-Qur'an Terengganu yang setakat ini dijumpai mempunyai sembilan buah di pelbagai tempat di dua buah Negara Malaysia dan Indonesia. Manuskrip al-Qur'an IAMM 2012.13.6 yang menjadi koleksi Muzium Kesenian Islam Malaysia telah dikelompokkan dari Terengganu berdasarkan kepada tiga aspek yang telah dibincangkan sebelum ini. Pengklasifikasian ini dibuat berdasarkan kajian lepas yang dibuat oleh pengkaji-pengkaji sebelum ini dan juga bahan bukti yang boleh dijadikan sandaran.

Sejarah penulisan al-Qur'an Terengganu dipercayai bermula seawal abad ke 18 sekiranya dilihat pada pengasas Kesultanan Terengganu yang bermula pada $1708 \mathrm{M}$. Namun begitu tidak ada bukti yang mengatakan terdapat aktiviti penulisan al-Qur'an pada waktu itu. Penulisan al-Qur'an di Terengganu sehingga kini tercatat pada manuskrip al-Qur'an yang menjadi koleksi di Muzium Kesenian Islam Malaysia pada tahun 1288 hijrah bersamaan 1872. Seterusnya, aktiviti penulisan berkembang sehingga ada manuskrip al-Qur'an Terengganu berada di luar sempadan negeri dan negara. Sejarah percetakan juga antara yang terawal di Malaysia apabila terdapat bukti yang menunjukkan ianya telah mula di cetak batu pada pada 20 Rabiulawal 1287 bersamaan 20 Jun 1870 di Singapura.

Adalah menjadi masalah utama kepada pengkaji-pengkaji manuskrip al-Qur'an dalam mengenalpasti asal usul sesuatu manuskrip terutamanya manuskrip al-Qur'an. Ini kerana kebanyakannya tidak mempunyai catatan kolofon yang menentukan penulis, tahun penghasilan dan tempat dihasilkan. Namun begitu, teori-teori yang berasaskan kepada ragan hiasan iluminasi, catatan sejarah dan kolofon yang berada pada manuskrip lain telah mengkelaskan sesuatu manuskrip al-Qur'an itu dalam kelompok yang sama. 
Manuskrip al-Quran Terengganu mempunyai jumlah yang agak banyak berbanding dengan manuskrip lain di Alam Melayu, oleh kerana itu ianya menjadi tumpuan beberapa orang pengkaji untuk menelitinya dengan lebih mendalam. Ciri-ciri yang hampir sama antara satu sama lain seperti iluminasi, kaligrafi dan kemewahan perada emasnya menjadi tarikan untuk diteliti dari pelbagai aspek. Daripada sembilan manuskrip al-Qur'an yang pengkaji temui, terdapat dua manuskrip al-Qur'an Terengganu yang mempunyai huraian tambahan seperti penerangan tanda wakaf dalam al-Qur'an dan huraian qira'at.

\section{Rujukan}

"Penulis tidak diketahui", Langkasuka, Sacred \& Profane (Kuala Lumpur: Akademi Nik Rashiddin, t.t.), 3.

"Sejarah Bima", laman sesawang Bimakab, dicapai 15 Feb 2017, http://bimakab. go. id/pages-sejarah-bima. html.

Abdullah Abdul Kdir Munsyi, Kesah Pelayaran Abdoellah bin Abdelkadir Moensji: dari Singapoera sampa ka negeri Kalantan (t. tp.: t.p., 1854), 18.

Ali Akbar (Penyelidik, Bayt al-Qur'an \& Muzium Istiqlal, Taman Mini Indonesia Indah, Jakarta), dalam temubual dengan pengkaji, 15 Jun 2012.

Ali Akbar (Penyelidik, Bayt al-Qur'an \& Muzium Istiqlal, Taman Mini Indonesia Indah, Jakarta), dalam temubual dengan pengkaji, 15 Jun 2012.

Ali Akbar (Penyelidik, Bayt al-Qur'an dan Muzium Istiqlal, Jakarta) dalam temubual dengan pengkaji, 1 Ogos 2016.

Ali Akbar et al., Khazanah Mushaf al-Qur'an Nusa Tenggara Barat (Jakarta: Lajnah Pentashihan al-Qur'an, 2016), 2.

Ali Akbar. "Qur'an-qur'an Istana Nusantara". Prosiding, International Conference on The Holy Quran, Aryaduta Hotel, Jakarta, 30 Ogos-1September 2016.

Al-Qur'an, (folio 614 dan 615), Terengganu, Seni Ukir Bakawali.

Al-Qur'an, no. IAMM 1998. 1. 3427 (folio 511-512), dalam The Islamic Arts Museum Malaysia - Volume 1 (Kuala Lumpur: Islamic Arts Museum Malaysia, 2002).

Al-Qur'an, no. IAMM 1998. 1. 3427 (folio 611), Kuala Lumpur, Muzium Kesenian Islam Malaysia. 
Al-Qur'an, no. IAMM 1998. 1. 3427(folio 303), Kuala Lumpur, Muzium Kesenian Islam Malaysia.

Al-Qur'an, no. IAMM 1998. 1. 3427(folio 603), Kuala Lumpur, Muzium Kesenian Islam Malaysia.

Al-Qur'an, no. IAMM 1998. 1. 3436 (folio 603), Kuala Lumpur, Muzium Kesenian Islam Malaysia.

Al-Qur'an, no. MSS 4136 (folio 2-3), Kuala Lumpur, Perpustakaan Negara Malaysia.

Al-Qur'an, no. PMM 885. 01. U1. 56 (folio 2 dan 3), Melaka, Muzium Kebudayaan Melaka.

Annabel Teh Gallop (Ketua Kurator, Bahagian Asia Tenggara British Library, London) dalam temubual melalui email dengan pengkaji, 1 Disember 2012.

Annabel Teh Gallop (Ketua seksyen Asia Tenggara, British Library, London), dalam temubual dengan pengkaji, 21 Mei 2014.

Annabel Teh Gallop, "The Art of the Qur'an in Southeast Asia," dalam Word of God, Art of Man, The Qur'an and its Creative Expressions, ed. Fahmida Suleman (Oxford: The Institute of Ismaili Studies London, 2010), 192.

Annabel Teh Gallop, "The Spirit of Langkasuka? Illuminated manuscripts from the East Coast of the Malay Peninsula", dalam Indonesia and the Malay World (London: Routledge, 2005) 84.

Annabel The Gallop, "The Spirit of Langkasuka?”.

Barkeshli dan Mandana. Islamic Arts Museum Malaysia (Kuala Lumpur: Islamic Arts Museum Malaysia, 2002).

Barkeshli et al., Nur al-Qur'an. Kuala Lumpur: Muzium Kesenian Islam Malaysia, 1999.

Faizal Hilmie bin Yusof (Ketua, Pusat Kebangsaan Manuskrip Melayu, Perpustakaan Negara Malaysia), dalam temubual dengan pengkaji, 15 Oktober 2015.

H. Muchlis et al. , Bayt al-Qur'an \& Museum Istiqlal (Indonesia: Lajnah Pentashihan Mushaf al-Qur'an dan Diklat Kementerian Agama RI, 2015).

Heba Nayel Barakat dan Nurul Iman Rusli, al-Qur'an; The Sacred Art of Revelation (Kuala Lumpur: Islamic Art Museum, 2014), II : 322. 
Heba Nayel Barakat dan Nurul Iman Rusli, al-Qur'an; The Sacred Art of Revelation, 323.

Ibn Kathīr, Ismā'îl bin 'Umar. Tafsìr al-Qur'ān al- 'Azīm. Beirut: Dār al-Kutub al-'Ilmiyyah, t.t.

Islah Gusmian (Pensyarah di Universitas Islam Negeri, Sunan Kalijaga, Yogyakarta, Indonesia), dalam temubual dengan pengkaji, 1 September 2016.

Mohamed Anuar Omar Din dan Nik Anuar Mahmud. Sejarah Kesultanan Terengganu 1708-2008. Kuala Terengganu: Yayasan DiRaja Sultan Mizan, 2011.

Mohamed Anuar Omar Din dan Nik Anuar Mahmud. Sejarah Lajnah Pentashihan al-Qur'an. Mushaf al-Qur'an di Indonesia. Jakarta: Badan Litbang Agama dan Diklat Kementerian Agama Republik Indonesia, 2011.

Muhamad Edzhar bin Muhamad Razali (Eksekutif Kanan bahagian Rekod dan Koleksi Eksklusif, Muzium Kesenian Islam Malaysia), dalam temubual dengan pengkaji, 27 Januari 2017.

Pemerintah Kabupaten Bima Nusa Tenggara Barat, "Sejarah Bima", laman sesawang Bimakab, dicapai 15 Feb 2017, http://bimakab. go. id/pages-sejarah-bima. html.

Riswadi Azmi. "Manuskrip al-Qur'an di Masjid Raya Sultan Riau; Kajian Diskriptif dan Analisis Teks Qira'at". Makalah, The International Symposium on Manuscript of Qur'an Science and Interpretations: The indexing, Definition, Description and Study, Center Of Quranic Research, Universiti Malaya, 29-30 Ogos 2012. 